\title{
DEVELOPING A SUCCESSFUL AEROTROPOLIS BY USING A HYBRID MODEL UNDER INFORMATION UNCERTAINTY
}

\author{
James J. H. LIOU ${ }^{*}$, Chao-Che HSU², Chun-Sheng Joseph LI ${ }^{3}$, \\ Pedro Jose Gudiel PINEDA ${ }^{1}$, Gin-Weng CHANG ${ }^{1}$ \\ ${ }^{1}$ Department of Industrial Engineering and Management, National Taipei University of Technology, \\ No. 1, Section 3, Chung-Hsiao East Road, Taipei 106, Taiwan \\ ${ }^{2}$ Department of Transportation Management, Tamkang University, \\ 151 Ying-Chuan Rd. Tamsui, Taipei 251, Taiwan \\ ${ }^{3}$ Department of International Business, \\ National Taichung University of Education,140 Min-Shen Rd., Taichung 403, Taiwan
}

Received 03 May 2016; accepted 29 January 2017

\begin{abstract}
Many airports are being expanded from transportation centers to economic hubs. This new type of urban area has been termed the aerotropolis or airport metropolis and is meant to function as an economic center with land-use that link local and global markets. However, to find the optimal means for developing an aerotropolis requires additional research, particularly from the viewpoint of long-term public policy and planning. In this study, a multiple criteria decision making model was applied to explore the key factors for successfully building an aerotropolis. We first applied the Decision-making Trial and Evaluation Laboratory based Analytical Network Process to construct the complex system and influential weights. A modified VIKOR method was then utilized to explore the gaps between the aspiration levels and the current situation. In addition, considering the uncertainty of decision-makers, fuzzy theory was integrated into the model. Data from the Taoyuan Aerotropolis in Taiwan were used to demonstrate this method. The results indicate that internationalization is the most crucial factor within the system, and that administrative efficiency has the highest degree of net influence. The largest weighted gap to the examined aspiration level is adequate regulation. Management implications are provided in the discussion.
\end{abstract}

Keywords: DEMATEL, DANP, MCDM, VIKOR, aerotropolis.

JEL Classification: C65, C83, O18, O21, R48.

\section{Introduction}

An aerotropolis is an urban subregion whose infrastructure, land-use, and economy are centered on an airport. Its primary value proposition is that it offers businesses speedy connectivity to their suppliers, customers, and enterprise partners nationally and worldwide,

*Corresponding author. E-mail: jamesjhliou@gmail.com

This is an Open Access article distributed under the terms of the Creative Commons Attribution License (http://creativecommons. $\mathrm{org} / \mathrm{licenses} / \mathrm{by} / 4.0 /$ ), which permits unrestricted use, distribution, and reproduction in any medium, provided the original author and source are credited. 
increasing both firm and regional efficiency (Kasarda 2014). The aerotropolis has increasingly become a portal to national and regional economic growth (Canaday 2000). The changing role and criticality of the airport to the national economy are highly significant. At the global level, air travel is expected to increase "between 200\% and 300\% between 2000 and 2030" (UK Department for Transport 2003). The creation of an aerotropolis can increase air transport demand and develop an airport's surrounding industries. Airport development strategy increasingly tends to extend the aerotropolis to stimulate new investment, foster employment, and create new business opportunities (Yeo et al. 2013).

Because of the advantages airports provide in the fast-paced global network economy, the aerotropolis is becoming attractive to businesses, particularly those dealing in international business and trade. Many airports (e.g., Amsterdam Schiphol, Singapore Changi, and Dallas-Fort Worth) have established real estate or property divisions to develop their landside commercial areas and foster development beyond airport boundaries. This new operational structure demonstrates that the airport is evolving from basic aeronautical infrastructure into a complex multifunctional enterprise that serves both aeronautical needs and commercial development (Kasarda 2006). However, the extension of the airport from air transport depot to international business hub is not without problems. In particular, managers who overemphasize physical infrastructure may fail to acknowledge the importance of social infrastructure and connectivity as essential elements of this new identity. Although the development of such a subregion has become an economic generator for some cities, prior studies regarding how to develop a successful aerotropolis are still relatively scare. The literature directly or indirectly related to how to develop an aerotropolis is limited. The focus in earlier studies has mainly been on the definition of the aerotropolis (Kasarda 2005, 2006; Charles et al. 2007; Keast et al. 2008) although there have recently been some studies which have applied qualitative methods to discuss the key factors for successful development (Wang, Hong 2011; Skouloudis et al. 2012). Yeo et al. (2013) did carry out a study where they applied a quantitative analysis method, multiple criteria decision-making (MCDM), but they neglected the interdependency of the system. Therefore, this study proposes an integrated MCDM method aimed at resolve two key questions. What are the key factors for developing a successful aerotropolis and what are the gaps between the current performance and aspirations for the developing aerotropolis?

The proposed model considers multiple criteria and uses the Decision-making Trial and Evaluation Laboratory (DEMATEL) based Analytical Network Process (DANP) (Peng, Tzeng 2013; Shen et al. 2014; Tsui et al. 2015) to construct an influence network relationship map (INRM) and determine the influential weights of factors for an aerotropolis. Then, we apply a modified VIKOR method (You et al. 2015; Shen et al. 2014) to establish the weighted gaps in priorities between performance and aspiration levels. The DANP method is used because it is effective at building the complex relationships between factors and at deriving the factor weights without further investigation (Liou et al. 2014). To avoid the shortcomings of the traditional VIKOR method, it is modified by replacing the relatively good choices with the aspiration levels so as to avoid the "stop-gap piecemeal" complication (Liou et al. 2016; Peng, Tzeng 2013). Furthermore, human judgments are often vague and complex, making it hard for decision makers to evaluate their preferences using an exact scale. Linguistic assessments 
can only be given instead of exact assessments. Therefore, fuzzy set theory is introduced into the proposed MCDM framework to solve such uncertainty problems (Xu, Yager 2008; Liu et al. 2015a, 2015b). To the best of our knowledge, this is the first paper to apply the DANP and modified VIKOR models to aerotropolis analysis while also considering information uncertainty.

This new hybrid MCDM model offers a method showing improvements and gaps that can solve the real world problems of transforming an airport into an aerotropolis. The contribution of this work is that it offers a quantitative model that can aid practitioners not only to identify the key factors for developing a successful aerotropolis but also to determine directions for improvement, according to gap analysis and INRM. This study employs data from Taiwan's Taoyuan Aerotropolis to demonstrate the model. The remainder of this paper is organized as follows. Section 1 introduces a brief review of the literature on the topic. Section 2 proposes the DANP and VIKOR methods in combination with the uncertain inputs used to prioritize the gaps for improvement. Section 3 demonstrates this proposed method with an empirical example by using data from Taoyuan Aerotropolis. Section 4 presents discussions on these matters and, finally, the last Section presents conclusions and closing remarks.

\section{Literature review}

Experts agree that the 21st century will be dominated by air transport, for both the domestic and international carriage of passengers and cargo. The airport, as a driver of regional growth, becomes more than merely a regional gateway; it functions as a city in itself, with living spaces for workers and their families, factories relying on airborne inputs and service industries located around the airport, and major road and rail infrastructure connections (Charles et al. 2007). However, the questions of how to define this new type of "airport city" and what are its main elements or functions are yet to be adequately addressed. Kasarda $(2005,2006)$ first promoted the aerotropolis concept but left the definition vague. Subsequent uses of the word have had different connotations. At times, "aerotropolis" refers to a busy hub airport - as when the Hong Kong or Memphis airports are referred to as aerotropolises. At other times, it refers to an aviation-intensive global economy - as when intercontinental supply chains are mapped. There are three terms with definitions that are distinct from busy hub airports and aviation-intensity per se: that of airport city, ground-based trade facilitation, and mega-region (Appold 2013). In research summarized below, "an aerotropolis is an urban complex whose layout, infrastructure, and economy are centered on an airport. Analogous in shape to the traditional metropolis made up of a central city and its rings of commuter-heavy suburbs, the aerotropolis consists of an airport city core and outlying corridors and clusters of aviation-linked businesses and associated residential developments" (Kasarda 2006). Today, the aerotropolis has become an economic generator and a gateway to international destinations and global markets that link regions. This requires specific industry clustering and infrastructure to provide the necessary support for global competition (Keast et al. 2008). Furthermore, the aerotropolis can attract a range of producer service firms whose executives and professionals frequently travel to distant sites or who bring in their clients by air for short-term visits. 
Although the aerotropolis phenomenon has been discussed in many articles in the media, academic discussions of it have been relatively few. Stevens et al. (2010) produced a model of the factors integral for evaluating the competitiveness of aerotropolises, including economic development, land-use, infrastructure, and governance. Furthermore, Baker and Freestone (2010) indicated that land development and cost are critical problems faced by stakeholders. Wang and Hong (2011) introduced the following competitiveness criteria: industrial diversification, aggressive construction, trade liberation, regulation rationalization, environmental convenience, globalized operations, and business management. Skouloudis et al. (2012) found that the indicators for a successful aerotropolis should include economic (economic indicators), environmental (environmental indicators), and social (labor practices and decent work, human rights, society, and product responsibility) factors. Yeo et al. (2013) used a MCDM model to evaluate the competitiveness of aerotropolises in East Asia, but they assumed the evaluation criteria to be independent. The afore-mentioned factors and their definitions are summarized in Table 1. Our model is based on the above factors and the actual environment in Taiwan. These articles have made great contributions to the academic literature, but none has considered the complex relationships between the factors and their importance. Because building a successful aerotropolis involves many stakeholders, the aggregation of those diverse and vague opinions is an important consideration. In addition, for a developing aerotropolis, the directions for improvement that can realize aspirations are crucial for decision makers. This study provides a hybrid MCDM model intended to answer the questions of improving directions and the vague opinions. The proposed methodology is introduced in next section.

Table 1. Factors and definitions for developing an aerotropolis

\begin{tabular}{|c|c|c|}
\hline Factors & Definition & References \\
\hline $\begin{array}{l}\text { Trans- } \\
\text { portation } \\
\text { system }\end{array}$ & $\begin{array}{l}\text { Transportation systems such as trains, shuttle } \\
\text { buses, taxis, and trams around the airport to } \\
\text { accelerate the inter-modal transfer of goods } \\
\text { and people. }\end{array}$ & $\begin{array}{l}\text { Janic and Reggiani (2002); Kim and } \\
\text { Park (2012); Keumi and Murakami } \\
\text { (2012); Yeo et al. }(2013)\end{array}$ \\
\hline $\begin{array}{l}\text { Transfer } \\
\text { system }\end{array}$ & $\begin{array}{l}\text { Availability of transfer systems to increase } \\
\text { flight selection and air routes. }\end{array}$ & $\begin{array}{l}\text { Barros et al. (2007); Chou et al. (2011); } \\
\text { Kratzsch and Sieg (2011) }\end{array}$ \\
\hline $\begin{array}{l}\text { Free trade } \\
\text { zone }\end{array}$ & $\begin{array}{l}\text { Developing/expanding the scale of the free } \\
\text { trade zone and providing a high quality } \\
\text { international free trading environment. }\end{array}$ & $\begin{array}{l}\text { Wang and Hong (2011); Skouloudis } \\
\text { et al. (2012); Yeo et al. (2013) }\end{array}$ \\
\hline $\begin{array}{l}\text { Land and } \\
\text { cost }\end{array}$ & $\begin{array}{l}\text { Whether enough land is located near the } \\
\text { airport to expand the scope of the aerotropolis } \\
\text { and the cost of renting the land. }\end{array}$ & $\begin{array}{l}\text { Menou et al. (2010); Stevens et al. } \\
\text { (2010); Yeo et al. (2013); Baker and } \\
\text { Freestone (2010) }\end{array}$ \\
\hline $\begin{array}{l}\text { Professional } \\
\text { personnel }\end{array}$ & $\begin{array}{l}\text { Whether enough experts are present who } \\
\text { have ability and experience related to } \\
\text { aerotropolis operation and management. }\end{array}$ & $\begin{array}{l}\text { Gardiner et al. (2005); Skouloudis et al. } \\
\text { (2012); Yeo et al. (2013) }\end{array}$ \\
\hline $\begin{array}{l}\text { Business } \\
\text { environment }\end{array}$ & $\begin{array}{l}\text { Public facilities for a comfortable resident } \\
\text { function (e.g., medical resources, education, } \\
\text { transportation, etc.) and commercial business } \\
\text { areas. }\end{array}$ & $\begin{array}{l}\text { Skouloudis et al. (2012); Yeo et al. } \\
\text { (2013); Wang et al. (2011); Kratzsch } \\
\text { and Sieg (2011) }\end{array}$ \\
\hline
\end{tabular}


End of Table 1

\begin{tabular}{|l|l|l|}
\hline \multicolumn{1}{|c|}{ Factors } & \multicolumn{1}{|c|}{ Definition } & \multicolumn{1}{|c|}{ References } \\
\hline $\begin{array}{l}\text { Preferential } \\
\text { program }\end{array}$ & $\begin{array}{l}\text { Relevant tax incentives for the industry park } \\
\text { setting, land rent, tariffs, and other measures } \\
\text { to encourage industrial clusters. }\end{array}$ & $\begin{array}{l}\text { Walker and Stevens (2008); Stevens } \\
\text { et al. (2010); Walker and Baker (2010); } \\
\text { Freestone } \text { et al. (2011) }\end{array}$ \\
\hline $\begin{array}{l}\text { Regulation } \\
\text { and policy }\end{array}$ & $\begin{array}{l}\text { Proper regulations for recruiting personnel } \\
\text { from international markets, business } \\
\text { activities, land use, etc. }\end{array}$ & $\begin{array}{l}\text { Walker and Stevens (2008); Walker and } \\
\text { Baker (2010); Wang et al. (2011) }\end{array}$ \\
\hline Sustainability & $\begin{array}{l}\text { Reduction of airplane noise and industry } \\
\text { pollution, an increase in forestation. }\end{array}$ & $\begin{array}{l}\text { Stevens et al. (2010); Wang et al. } \\
\text { (2011); Skouloudis et al. (2012); }\end{array}$ \\
\hline $\begin{array}{l}\text { Leisure and } \\
\text { tourism }\end{array}$ & $\begin{array}{l}\text { Shopping centers, hotels and tourism features } \\
\text { around the airport providing people with rest } \\
\text { and shopping destinations. }\end{array}$ & $\begin{array}{l}\text { Pagliari (2005); Rendeiro and Cejas } \\
\text { (2006); Wang and Hong (2011); Yeo } \\
\text { et al. (2013) }\end{array}$ \\
\hline $\begin{array}{l}\text { Geographic } \\
\text { location }\end{array}$ & $\begin{array}{l}\text { Whether the aerotropolis has a superior } \\
\text { geographic location to attract passengers, } \\
\text { cargo and companies. }\end{array}$ & $\begin{array}{l}\text { Jayalath and Bandara (2001); Yeo et al. } \\
\text { (2013) }\end{array}$ \\
\hline
\end{tabular}

\section{Methodology}

This section introduces a fuzzy DEMATEL-based Analytic Network Process (ANP) method for constructing the interdependent structure of factors and obtaining their influential weights. The fuzzy VIKOR method was used to analyze the weighted gaps. Doing so can enable decision makers to understand the complex relationships between factors and the key considerations in building a successful aerotropolis.

\subsection{Fuzzy DEMATEL}

To understand the interdependencies among key success factors, we first apply fuzzy logic and DEMATEL to build the network relationship.

Step 1. Build the direct influence matrix $(\tilde{\boldsymbol{A}})$ according to linguistic variables

The Triangle Fuzzy Numbers (TFNs) and linguistic variables used in this study are shown in Table 2. The pairwise interaction between any two factors is denoted by $\tilde{a}_{i j}$ and is given a TFN score ranging from 0 to 1 (Table 2). The scores from each expert give us an $n \times n$ non-

Table 2. The linguistic variables and the TFNs

\begin{tabular}{|c|l|c|}
\hline Fuzzy number & \multicolumn{1}{|c|}{ Linguistic variable } & TFN \\
\hline $0 . \tilde{0} 0$ & No influence & $(0.0,0.0,0.25)$ \\
\hline $0 . \tilde{2} 5$ & Low influence & $(0.0,0.25,0.5)$ \\
\hline $0 . \tilde{5} 0$ & Medium influence & $(0.25,0.5,0.75)$ \\
\hline $0 . \tilde{7} 5$ & High influence & $(0.5,0.75,1.0)$ \\
\hline $1 . \tilde{0} 0$ & Very high influence & $(0.75,1.0,1.0)$ \\
\hline
\end{tabular}


negative answer matrix $\tilde{\boldsymbol{X}}^{k}$, with $1 \leq k \leq H$. We can then compute the $n \times n$ average matrix $\tilde{\boldsymbol{A}}$ for all expert opinions by averaging the $H$ experts' scores as Eq. (1), where $l, m$, and $u$ represent the lower, middle, and upper bounds, respectively.

$$
\tilde{\boldsymbol{A}}=\left[\tilde{a}_{i j}\right]_{n \times n}=\left[\frac{1}{H} \sum_{h=1}^{H}\left(a_{i j}^{l}, a_{i j}^{m}, a_{i j}^{u}\right)^{h}\right]_{n \times n} .
$$

Step 2. Normalize the initial fuzzy influence matrix

A normalized initial fuzzy influence matrix $(\tilde{\boldsymbol{N}})$ is obtained by dividing the direct average matrix $\tilde{\boldsymbol{A}}$ by $\tilde{\boldsymbol{s}}$ according to the ratios given in Eq. (2). Through the calculation of Eq. (2), the normalized matrix can be represented by three crisp matrices $N^{l}, N^{m}$, and $N^{u}$.

$$
\begin{gathered}
\tilde{\boldsymbol{N}}=\left[\tilde{n}_{i j}\right]_{n \times n}=\left[\frac{\tilde{a}_{i j}}{\tilde{s}}\right]=\left[\left(\frac{a_{i j}^{l}}{s^{u}}, \frac{a_{i j}^{m}}{s^{m}}, \frac{a_{i j}^{u}}{s^{l}}\right)\right]_{n \times n} \text { in which } \\
\boldsymbol{N}^{p}=\boldsymbol{A}^{p} / s^{p}, \text { then } \boldsymbol{N}^{p}=\left[n_{i j}^{p}\right]_{n \times n}=\left[\left(a_{i j}^{p} / s^{p}\right)\right]_{n \times n}, \\
s^{p}=\left[\left(\max _{1 \leq j \leq n} \sum_{j=1}^{n} a_{i j}^{p}, \max _{1 \leq i \leq n} \sum_{i=1}^{n} a_{i j}^{p}\right)\right]_{n \times n}, p=l, m, u .
\end{gathered}
$$

Step 3. Derive the fuzzy total influence matrix

A continuous decrease of the indirect effects of problems along the powers of matrix $\tilde{\boldsymbol{N}}$ guarantees convergent solutions to the matrix inversion in a manner similar to that of an absorbing Markov chain matrix (Liou et al. 2014; Wang, Tzeng 2012). The total relation matrix $\tilde{\boldsymbol{T}}$ is a $n \times n$ matrix.

$$
\begin{gathered}
\tilde{\boldsymbol{T}}=\tilde{\boldsymbol{N}}^{1}+\tilde{\boldsymbol{N}}^{2}+\ldots+\tilde{\boldsymbol{N}}^{m}= \\
\tilde{\boldsymbol{N}}\left(\tilde{\boldsymbol{I}}-\tilde{\boldsymbol{N}}^{m}\right)(\tilde{\boldsymbol{I}}-\tilde{\boldsymbol{N}})^{-1}, \text { when } \lim _{m \rightarrow \infty} \tilde{\boldsymbol{N}}^{m}=[0]_{n \times n}=\tilde{\boldsymbol{N}}(\tilde{\boldsymbol{I}}-\tilde{\boldsymbol{N}})^{-1} .
\end{gathered}
$$

Step 4. Build the fuzzy influence network relationship

We can define the sum of rows and sum of columns separately denoted as vectors $\tilde{r}_{i}$ and $\tilde{d}_{i}$, respectively, within the total-influence matrix $\tilde{\boldsymbol{T}}$ through Eqs. (4) and (5), then

$$
\begin{gathered}
\tilde{r}_{i}=\left(\tilde{r}_{i}\right)_{n \times 1}=\left(\sum_{j=1}^{n} \tilde{t}_{i j}\right)_{n \times 1}=\left(r_{i}^{l}, r_{i}^{m}, r_{i}^{u}\right)_{n \times 1} ; \\
\tilde{d}_{i}=\left(\tilde{d}_{j}\right)_{n \times 1}=\left(\tilde{d}_{j}\right)_{1 \times n}^{\prime}=\left(\sum_{i=1}^{n} \tilde{t}_{i j}\right)_{1 \times n}=\left(d_{i}^{l}, d_{i}^{m}, d_{i}^{u}\right)_{1 \times n},
\end{gathered}
$$

where $i, j \hat{\mathrm{I}}\{1,2, \ldots, n\}$ and let $i=j$, then

$$
\begin{aligned}
& \tilde{r}_{i}+\tilde{d}_{i}=\left(r_{i}^{l}+d_{i}^{l}, r_{i}^{m}+d_{i}^{m}, r_{i}^{u}+d_{i}^{u}\right) ; \\
& \tilde{r}_{i}-\tilde{d}_{i}=\left(r_{i}^{l}-d_{i}^{u}, r_{i}^{m}-d_{i}^{m}, r_{i}^{u}-d_{i}^{l}\right),
\end{aligned}
$$

where superscript ' denotes transpose. 
Suppose $\tilde{r}_{i}$ denotes the row sum of the $i$-th row matrix $\tilde{\boldsymbol{T}}$; then, $\tilde{r}_{i}$ denotes the sum of direct and indirect effects of criterion $i$ on the other criteria. Suppose $\tilde{d}_{i}$ denotes the column sum of the $j$-th column of matrix $\tilde{\boldsymbol{T}}$; then, $\tilde{d}_{i}$ denotes the sum of direct and indirect effects that criterion $j$ has received from the other criteria. If $\left(\tilde{r}_{i}-\tilde{d}_{i}\right)$ is positive, then criterion $i$ affects other criteria, and if $\left(\tilde{r}_{i}-\tilde{d}_{i}\right)$ is negative, then criterion $i$ receives influence from other criteria.

\subsection{Fuzzy DEMATEL-based ANP}

In ANP procedures, the initial step is to tabulate pairwise comparisons of all the criteria in the whole system to form an unweighted supermatrix. The weighted supermatrix is then derived by transforming each column to sum exactly to unity (1.00). This paper adopts the DEMATEL technique to determine the degrees of influence of these criteria, and the procedures can be summarized as the following steps.

Step 1. Obtaining the fuzzy total influence matrix $\tilde{\boldsymbol{T}}_{C}$ and $\tilde{\boldsymbol{T}}_{D}$

Using Eq. (3), we can obtain the fuzzy total influence matrices $\tilde{\boldsymbol{T}}_{C}$ and $\tilde{\boldsymbol{T}}_{D}$ for criteria (also known as factors) and dimensions, respectively. Each fuzzy total influence matrix includes three crisp matrices to represent its low, middle, and upper bounds, as shown in Eqs. (8-10). To save space, we list only lower matrix $\tilde{\boldsymbol{T}}_{C}$; the middle and upper matrices are similar except that the index $l$ is replaced by $m$ and $u$, respectively. $\tilde{\boldsymbol{T}}_{D}$ can be obtained by averaging the fuzzy influence values of elements within the same dimension.

$$
\begin{aligned}
& \tilde{\boldsymbol{T}}_{C}=\left(\boldsymbol{T}_{C}^{l}, \boldsymbol{T}_{C}^{m}, \boldsymbol{T}_{C}^{u}\right) ; \\
& \tilde{\boldsymbol{T}}_{D}=\left(\boldsymbol{T}_{D}^{l}, \boldsymbol{T}_{D}^{m}, \boldsymbol{T}_{D}^{u}\right) ;
\end{aligned}
$$

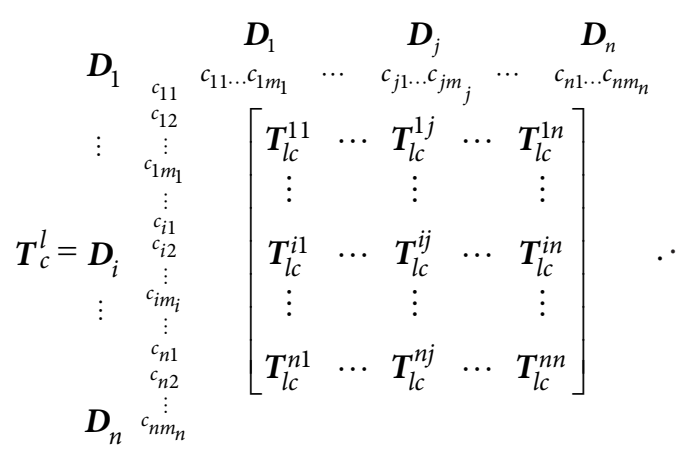

Step 2. Establishing the unweighted supermatrices $\tilde{\boldsymbol{W}}_{C}$ and $\tilde{\boldsymbol{W}}_{D}$

In the traditional normalization method, each criterion in a column is divided by the number of dimensions (sectors) so that each column will sum to unity exactly. In this study, we normalize the fuzzy total influence matrices $\tilde{\boldsymbol{T}}_{C}$ and $\tilde{\boldsymbol{T}}_{D}$ into $\tilde{\boldsymbol{T}}_{C}^{\alpha}$ and $\tilde{\boldsymbol{T}}_{D}^{\alpha}$ through Eqs. (11-15), which maintain their original ratios but can reflect the various degrees of their influences according to the DEMATEL results. The normalized $\tilde{\boldsymbol{T}}_{C}^{\alpha}$ comprises three crisp matrices, as shown in Eq. (11). 


$$
\tilde{\boldsymbol{T}}_{C}^{\alpha}=\left(\boldsymbol{T}_{C}^{\alpha l}, \boldsymbol{T}_{C}^{\alpha m}, \boldsymbol{T}_{C}^{\alpha u}\right) .
$$

Only the lower bound matrix is shown in Eq. (12); however, the middle and upper bound matrices can be derived using the same procedures.

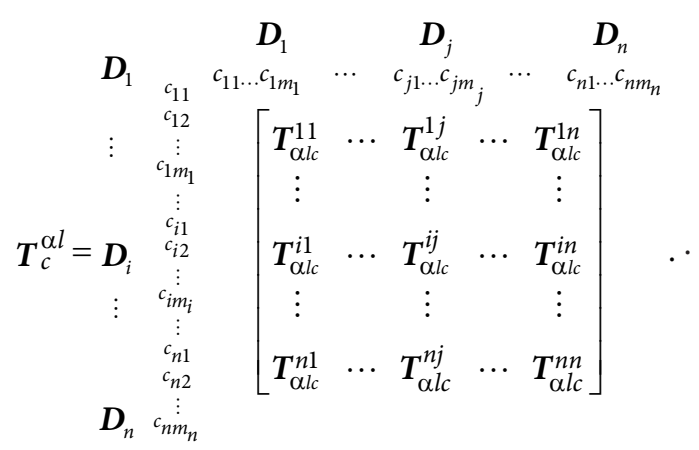

The elements of $T_{C}^{\alpha}$ can be found using an example of submatrix $\boldsymbol{T}_{\alpha l C}^{11}$, as shown in Eqs. (13) and (14).

$$
\begin{aligned}
& d_{l i}^{11}=\sum_{j=1}^{m_{1}} t_{C}^{11}{ }^{11}, i=1,2, \ldots, m_{1} ;
\end{aligned}
$$

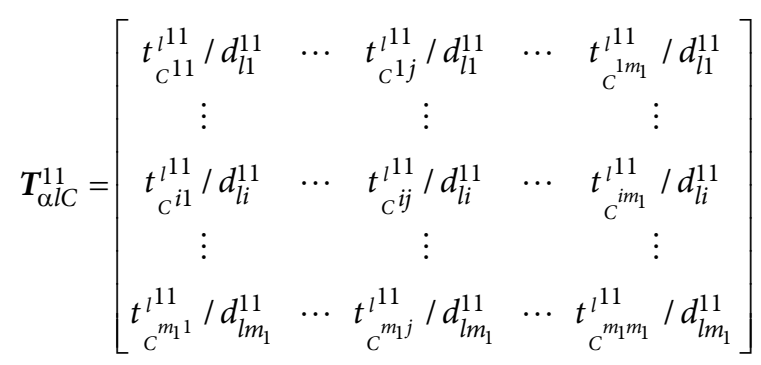

$$
\begin{aligned}
& =\left[\begin{array}{ccccc}
t_{l C^{11}}^{\alpha 11} & \cdots & t_{l C^{1 j}}^{\alpha 11} & \cdots & t_{l_{C}^{1 m_{1}}}^{\alpha 11} \\
\vdots & & \vdots & & \vdots \\
t_{l C^{i 1}}^{\alpha 11} & \cdots & t_{l C^{i j}}^{\alpha 11} & \cdots & t_{l_{C}^{i m_{1}}}^{\alpha 11} \\
\vdots & & \vdots & & \vdots \\
t^{\alpha 11} & \cdots & t^{\alpha 11}{ }_{l c^{m_{1} 1}}^{\alpha 11} & \cdots & t^{\alpha 11}{ }^{m_{1} m_{1}}
\end{array}\right] .
\end{aligned}
$$

The unweighted supermatrices $\left(\tilde{\boldsymbol{W}}_{C}\right.$ and $\tilde{\boldsymbol{W}}_{D}$ ) for criteria and dimensions can be derived from Eqs. (15) and (16). 


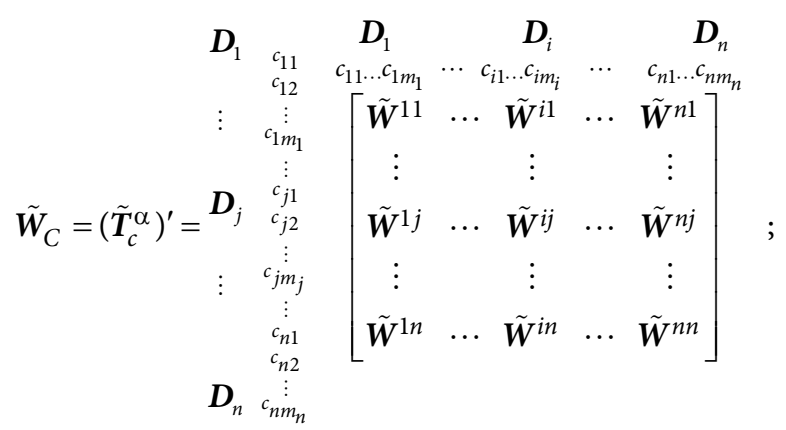

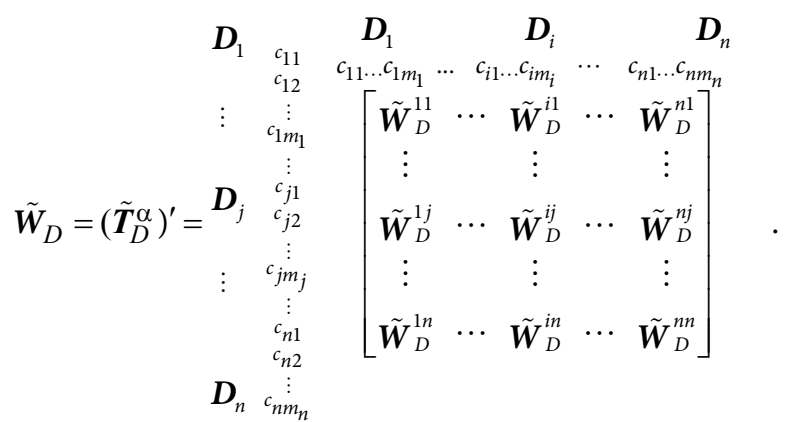

One element of these unweighted supermatrices is illustrated in Eq. (17).

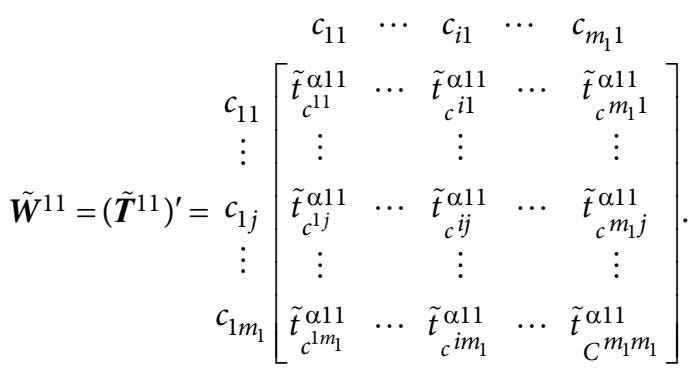

Step 3. Creating the weighted supermatrix $\left(\tilde{\boldsymbol{W}}^{\alpha}\right)$

According to $\tilde{\boldsymbol{W}}_{C}$ and $\tilde{\boldsymbol{W}}_{D}$, the fuzzy weighted supermatrix $\tilde{\boldsymbol{W}}^{\alpha}$ can be calculated using Eq. (18). It should be noted that this weighted supermatrix considers the different degrees of influence between dimensions which is different from the original ANP method. 


$$
\tilde{\boldsymbol{W}}^{\alpha}=\tilde{\boldsymbol{W}}_{D} \times \tilde{\boldsymbol{W}}_{C}=\left[\begin{array}{ccccc}
\tilde{W}_{D}^{11} \times \tilde{\boldsymbol{W}}^{11} & \cdots & \tilde{W}_{D}^{i 1} \times \tilde{\boldsymbol{W}}^{i 1} & \cdots & \tilde{W}_{D}^{n 1} \times \tilde{\boldsymbol{W}}^{n 1} \\
\vdots & & \vdots & & \vdots \\
\tilde{W}_{D}^{1 j} \times \tilde{\boldsymbol{W}}^{1 j} & \cdots & \tilde{W}_{D}^{i j} \times \tilde{\boldsymbol{W}}^{i j} & \cdots & \tilde{W}_{D}^{n j} \times \tilde{\boldsymbol{W}}^{n j} \\
\vdots & & \vdots & & \vdots \\
\tilde{W}_{D}^{1 n} \times \tilde{\boldsymbol{W}}^{1 n} & \cdots & \tilde{W}_{D}^{i n} \times \tilde{\boldsymbol{W}}^{i n} & \cdots & \tilde{W}_{D}^{n n} \times \tilde{\boldsymbol{W}}^{n n}
\end{array}\right] .
$$

\section{Step 4. Limiting supermatrix $\left(\tilde{\boldsymbol{W}}^{*}\right)$}

The weighted supermatrix can be raised to limiting powers until the supermatrix has converged and become a long-term stable supermatrix.

$$
\lim _{z \rightarrow \infty}\left(\tilde{\boldsymbol{W}}^{\alpha}\right)^{z}
$$

\subsection{Using the fuzzy VIKOR method to find the weighted gap values}

In this study, the VIKOR method shows how to set the strategic systems to improve and reduce the gaps from existing performance-values. Development of the VIKOR method began with the following traditional additive form of the $L_{v}$-metric (Tzeng et al. 2002):

$$
\tilde{L}_{k}^{v}=\left\{\sum_{j=1}^{n}\left[\tilde{w}_{j}\left(\left|\tilde{f}_{j}^{*}-\tilde{f}_{k j}\right|\right) /\left(\left|\tilde{f}_{j}^{*}-\tilde{f}_{j}^{-}\right|\right)\right]^{v}\right\}^{1 / v},
$$

where $1 \leq v \leq \infty ; k=1,2, \ldots m$ and the influence weight $\tilde{w}_{j}$ is derived from the DANP. For the ranking and weighting gaps, the measures $\tilde{L}_{k}^{v=1}$ and $\tilde{L}_{k}^{v=\infty}$ are used (Opricovic, Tzeng 2004).

$$
\begin{gathered}
\tilde{L}_{k}^{v=1}=\sum_{j=1}^{n}\left[\tilde{w}_{j}\left(\left|\tilde{f}_{j}^{*}-\tilde{f}_{k j}\right|\right) /\left(\left|\tilde{f}_{j}^{*}-\tilde{f}_{j}^{-}\right|\right)\right] ; \\
\tilde{L}_{k}^{v=\infty}=\max _{j}\left\{\left(\left|\tilde{f}_{j}^{*}-\tilde{f}_{k j}\right|\right) /\left(\left|\tilde{f}_{j}^{*}-\tilde{f}_{j}^{-}\right|\right) \mid j=1,2, \ldots, n\right\} .
\end{gathered}
$$

The compromise solution $\min L_{k}^{v}$ shows the aggregated gap-ratio to be minimized by the additive form, as given in $\mathrm{E}_{\mathrm{q}}^{k}$. (21). For the criterion in each dimension, $\tilde{L}_{k}^{v=\infty}$ shows the priority for improvement of the maximal gap-ratio; this is shown for all criteria by Eq. (22). In this study, we modified the original approach and set the best $f_{j}^{*}$ values to be the aspiration levels and the worst $f_{j}^{-}$values as the tolerable levels for all criterion functions, $j=1,2, \ldots n$., and all the values are expressed as TFNs to reflect this problem's uncertainty.

In this study, we represent $\tilde{S}_{i}$ (group utility) and $\tilde{Q}_{i}$ (maximum regret) according to Eqs. (21) and (22), respectively. The gap value $\tilde{R}_{i}$ can be computed as Eq. (23):

$$
\tilde{R}_{i}=\gamma\left(\tilde{S}_{i}-\tilde{S}^{*}\right) /\left(\tilde{S}^{-}-\tilde{S}^{*}\right)+(1-v)\left(\tilde{Q}_{i}-\tilde{Q}^{*}\right) /\left(\tilde{Q}^{-}-\tilde{Q}^{*}\right)
$$

where $0 \leq \gamma \leq 1 ; \gamma>0.5$ indicates that $\tilde{S}$ is emphasized more than $\tilde{Q}$, whereas $\gamma<0.5$ indicates that $\tilde{Q}$ is emphasized more than $\tilde{S}$. 


\subsection{Defuzzification}

After deriving the weighted gaps for lower, middle, and upper bounds, we defuzzify the fuzzy weighted gaps. In this paper, we choose the center of area defuzzification method to determine the best nonfuzzy performance (BNP) value of our fuzzy numbers because it is simple and practical. The BNP value of the fuzzy number can be calculated as Eq. (24) (Chen et al. 2011).

$$
R=\left[\left(R^{u}-R^{l}\right)+\left(R^{m}-R^{l}\right)\right] / 3+R^{l}
$$

\section{Taiwan aerotropolis case study}

Although an airport can provide striking advantages, an aerotropolis can provide overwhelming advantages in today's fast-paced global network economy; thus the aerotropolis phenomenon is becoming conspicuously attractive to businesses, particularly those dealing in international business and trade. For sectors ranging from pharmaceuticals to semiconductor fabrication to management consulting, the reasons to locate near airports have become evident as customers and suppliers have spanned around the globe. Taiwan is a small island, renowned in global electronics supply chains; electronics exports comprise more than $70 \%$ of Taiwan's GDP. The short life cycle of electronic designs is a crucial characteristic of electronic products. Electronic product manufacturers require efficient production and logistics systems to manufacture and deliver products to customers around the world. Because an aerotropolis would be a boon for Taiwanese industries, the Taiwan government began the Taoyuan Aerotropolis project in 2010. The government first privatized the Taiwan Taoyuan International Airport and established Taoyuan Aerotropolis Company to integrate and manage the different resources and stakeholders. However, the project has faced numerous problems, including land expropriation difficulties, inadequate regulation, and insufficient infrastructure. At present, it is vital that the Taiwan government understand the key factors for success and the directions in which the project must improve so that the aerotropolis will achieve the goals to which the stakeholders aspire. The Taiwan government must make effective strategic decisions to develop the aerotropolis successfully.

\subsection{Identify factors for developing the aerotropolis}

Because the aerotropolis is an emerging phenomenon, no consensus exists among researchers and practitioners regarding the factors that determine the success or failure of an aerotropolis project. In this study, the criteria for a successful project are constructed in two steps: a literature review and case-based survey. The first step considers the aerotropolis qualities that are widely believed be relevant. From a review of numerous articles discussing aerotropolises (e.g., Kasarda 2005, 2006, 2014; Stevens et al. 2010; Baker, Freestone 2010; Wang; Hong 2011; Freestone et al. 2011; Skouloudis et al. 2012; Yeo et al. 2013; Kratzsch, Sieg 2011), 26 significant factors were identified and classified in four dimensions, each with six to eight factors. After consulting with three experts (one from Taoyuan International Airport Corporation, one from Taoyuan Aerotropolis Company, and one from the Taiwan government), we modi- 
fied and added some factors to reflect the particular details of the operational environment in Taiwan. In the second step, through a questionnaire, we asked 13 experts from related departments (i.e., government, industries, airport) to rank the importance of each criterion with respect to the development of a successful aerotropolis. All experts consulted in this study had more than 5 years working experience in the development of the aerotropolis in Taiwan. Some of them have worked for the Taoyuan Aerotropolis since the government first launched the project. They were thus able to reflect on real situations at the current stage of development. In the questionnaire, the experts of different departments were asked to rate the importance levels of criteria on a 6-point scale ranging from 0 (no effect) to 5 (extremely important). Finally, the highest scoring criteria in each dimension were extracted and confirmed by managers and experts. These criteria were then used to construct a system for assessing the aerotropolis. Based on this evaluation process, the evaluation factors within each dimension were identified, as shown in Table 3. The system includes five dimensions and 15 factors, all of which are introduced briefly as follows. When an enterprise wants to establish a presence in the aerotropolis, the required budgets for land, labor, and utilities are classified as the dimension of "cost." The "government" dimension includes the notions that the Taiwan government intends to provide the necessary preferential program that will attract enterprises to move in, and that the government will establish regulations to manage the operation of the aerotropolis. The "infrastructure" comprises the airport, air routes, free port zone, and ground transportation system. The factors of industrialization and internationalization are classified as the "business environment." The operation model, enterprise recruitment, and professional personnel in Taoyuan Aerotropolis Company are all classified as "management."

Table 3. Factors and dimensions for evaluating Taoyuan aerotropolis

\begin{tabular}{|c|l|l|}
\hline \multicolumn{1}{|c|}{ Dimensions } & \multicolumn{1}{|c|}{ Criteria/factors } & \multicolumn{1}{c|}{ Factor explanation } \\
\hline \multirow{5}{*}{ Cost } & Land $\left(\mathrm{C}_{11}\right)$ & $\begin{array}{l}\text { The cost for enterprises to obtain or rent land in the } \\
\text { aerotropolis }\end{array}$ \\
\cline { 2 - 4 } & Labor $\left(\mathrm{C}_{12}\right)$ & The cost of labor in the aerotropolis \\
\cline { 2 - 4 } & Utility $\left(\mathrm{C}_{13}\right)$ & $\begin{array}{l}\text { The cost of water, electricity, and other resources } \\
\text { required for industrial operations }\end{array}$ \\
\hline \multirow{5}{*}{ Government } & $\begin{array}{l}\text { Administrative } \\
\text { efficiency }\left(\mathrm{C}_{21}\right)\end{array}$ & $\begin{array}{l}\text { Government departments provide efficient services for } \\
\text { enterprises residing and operating in the aerotropolis }\end{array}$ \\
\cline { 2 - 4 } & $\begin{array}{l}\text { Preferential } \\
\text { program }\left(\mathrm{C}_{22}\right)\end{array}$ & $\begin{array}{l}\text { Provide favorable revenue measures, tariffs reductions, } \\
\text { or other incentives to attract enterprises }\end{array}$ \\
\cline { 2 - 4 } & $\begin{array}{l}\text { Adequate regulation } \\
\left(\mathrm{C}_{23}\right)\end{array}$ & $\begin{array}{l}\text { Proper regulations for recruiting personnel from } \\
\text { international markets, business activities, land use, etc. }\end{array}$ \\
\hline Airport $\left(\mathrm{C}_{31}\right)$ & $\begin{array}{l}\text { Airport has enough runways, terminals, aprons, ICQ } \\
\text { systems, and other required facilities }\end{array}$ \\
\cline { 2 - 4 } & Air routes $\left(\mathrm{C}_{32}\right)$ & $\begin{array}{l}\text { Network of air routes connected to other major cities } \\
\text { around the world }\end{array}$ \\
\cline { 2 - 4 } & $\begin{array}{l}\text { Ground } \\
\text { transportation }\left(\mathrm{C}_{33}\right)\end{array}$ & $\begin{array}{l}\text { The transportation in the aerotropolis area and } \\
\text { connections to other cities such as railroads or highway } \\
\text { systems }\end{array}$ \\
\hline
\end{tabular}


End of Table 3

\begin{tabular}{|c|c|c|}
\hline Dimensions & Criteria/factors & Factor explanation \\
\hline & Free port zone $\left(\mathrm{C}_{34}\right)$ & $\begin{array}{l}\text { A place where imported merchandise may be stored } \\
\text { duty-free pending re-export or duty-paid entry into the } \\
\text { importing country }\end{array}$ \\
\hline \multirow{2}{*}{$\begin{array}{l}\text { Business } \\
\text { Environment }\end{array}$} & $\begin{array}{l}\text { Industrialization } \\
\left(\mathrm{C}_{41}\right)\end{array}$ & $\begin{array}{l}\text { The development of industries on an extensive scale in } \\
\text { Taiwan }\end{array}$ \\
\hline & $\begin{array}{l}\text { Internationalization } \\
\left(\mathrm{C}_{42}\right)\end{array}$ & $\begin{array}{l}\text { The growing tendency of corporations to operate } \\
\text { across borders and the involvement of enterprises in } \\
\text { international markets }\end{array}$ \\
\hline \multirow{3}{*}{ Management } & $\begin{array}{l}\text { Operational model } \\
\left(\mathrm{C}_{51}\right)\end{array}$ & $\begin{array}{l}\text { The operational or business model of Taoyuan } \\
\text { Aerotropolis Company that integrates and manages the } \\
\text { various stakeholders }\end{array}$ \\
\hline & $\begin{array}{l}\text { Enterprise } \\
\text { recruitment }\left(\mathrm{C}_{52}\right)\end{array}$ & $\begin{array}{l}\text { The processes or activities of finding and inviting the } \\
\text { best-qualified enterprises to Taoyuan Aerotropolis in a } \\
\text { timely and cost-effective manner }\end{array}$ \\
\hline & $\begin{array}{l}\text { Professional } \\
\text { personnel }\left(\mathrm{C}_{53}\right)\end{array}$ & $\begin{array}{l}\text { Taoyuan Aerotropolis Company has enough professional } \\
\text { employees to manage the aerotropolis and make profit }\end{array}$ \\
\hline
\end{tabular}

\subsection{Measure the relationships between factors}

According to the evaluating system summarized in Table 3 and the DANP procedures described in Section 3, experts and managers were asked to evaluate the degrees of influence of the relationships among the factors using the linguistic variables (Table 2). The average initial direct-relation matrix $\tilde{\boldsymbol{A}}$ was a $15 \times 15$ matrix, obtained by pairwise comparisons, in terms of the directional influences between factors (see Appendix). Because linguistic variables were used in the survey, those linguistic variables were then transformed into fuzzy numbers according to Table 2 . The normalized direct-relation matrix $\tilde{N}$ was calculated through Eq. (2). Then, using Eq. (3), the total-influence matrix $\tilde{\boldsymbol{T}}$ was derived. Eq. (4) and (5) yielded the influence exerted $(\tilde{r}-\tilde{d})$ and received $(\tilde{r}+\tilde{d})$ for each factor, as shown in Table 4 . Furthermore, according to the total influence matrix $\tilde{\boldsymbol{T}}$ between factors, we derived the total influence matrix between dimensions by averaging the degrees of influence of factors within each dimension (Table 5).

Table 4. Sum of influences exerted on and received between factors

\begin{tabular}{|c|c|c|c|c|c|c|}
\hline $\begin{array}{c}\text { Fac- } \\
\text { tors }\end{array}$ & $\tilde{r}$ & $\tilde{d}$ & $\tilde{r}+\tilde{d}$ & BNP & $\tilde{r}-\tilde{d}$ & BNP \\
\hline $\mathrm{C}_{11}$ & $(1.72,2.28,3.91)$ & $(1.80,2.35,3.97)$ & $(3.52,4.64,7.88)$ & 5.35 & $(-2.25,-0.07,2.11)$ & -0.07 \\
\hline $\mathrm{C}_{12}$ & $(1.72,2.20,3.76)$ & $(2.55,3.08,4.65)$ & $(4.27,5.28,8.41)$ & 5.99 & $(-2.94,-0.87,1.2)$ & -0.87 \\
\hline $\mathrm{C}_{13}$ & $(1.57,2.11,3.72)$ & $(1.22,1.70,3.23)$ & $(2.79,3.82,6.96)$ & 4.52 & $(-1.66,0.41,2.51)$ & 0.42 \\
\hline $\mathrm{C}_{21}$ & $(1.77,2.31,3.94)$ & $(1.11,1.57,3.15)$ & $(2.88,3.88,7.09)$ & 4.61 & $(-1.38,0.74,2.83)$ & 0.73 \\
\hline $\mathrm{C}_{22}$ & $(1.62,2.13,3.71)$ & $(1.15,1.69,3.28)$ & $(2.77,3.83,6.99)$ & 4.53 & $(-1.66,0.44,2.56)$ & 0.45 \\
\hline $\mathrm{C}_{23}$ & $(1.54,2.09,3.69)$ & $(1.31,1.78,3.33)$ & $(2.84,3.87,7.02)$ & 4.58 & $(-1.80,0.31,2.38)$ & 0.30 \\
\hline
\end{tabular}


End of Table 4

\begin{tabular}{|l|c|c|c|c|c|c|}
\hline $\begin{array}{c}\text { Fac- } \\
\text { tors }\end{array}$ & $\tilde{r}$ & $\tilde{d}$ & $\tilde{r}+\tilde{d}$ & BNP & $\tilde{r}-\tilde{d}$ & BNP \\
\hline $\mathrm{C}_{31}$ & $(1.69,2.25,3.85)$ & $(1.81,2.35,3.93)$ & $(3.50,4.60,7.78)$ & 5.29 & $(-2.24,-0.1,2.04)$ & -0.10 \\
\hline $\mathrm{C}_{32}$ & $(1.65,2.17,3.72)$ & $(1.77,2.28,3.86)$ & $(3.42,4.45,7.58)$ & 5.15 & $(-2.21,-0.11,1.95)$ & -0.12 \\
\hline $\mathrm{C}_{33}$ & $(1.88,2.39,3.99)$ & $(2.10,2.66,4.23)$ & $(3.98,5.05,8.22)$ & 5.75 & $(-2.35,-0.27,1.89)$ & -0.24 \\
\hline $\mathrm{C}_{34}$ & $(1.35,1.96,3.57)$ & $(1.40,2.00,3.63)$ & $(2.75,3.96,7.20)$ & 4.64 & $(-2.28,-0.04,2.17)$ & -0.05 \\
\hline $\mathrm{C}_{41}$ & $(1.46,1.88,3.35)$ & $(1.90,2.48,4.07)$ & $(3.36,4.37,7.42)$ & 5.05 & $(-2.61,-0.6,1.45)$ & -0.58 \\
\hline $\mathrm{C}_{42}$ & $(1.66,2.20,3.75)$ & $(2.17,2.71,4.26)$ & $(3.83,4.91,8.01)$ & 5.58 & $(-2.60,-0.51,1.58)$ & -0.51 \\
\hline $\mathrm{C}_{51}$ & $(1.59,2.09,3.65)$ & $(1.24,1.78,3.36)$ & $(2.83,3.87,7.02)$ & 4.57 & $(-1.77,0.31,2.41)$ & 0.32 \\
\hline $\mathrm{C}_{52}$ & $(1.49,2.00,3.53)$ & $(1.37,1.94,3.55)$ & $(2.86,3.95,7.08)$ & 4.63 & $(-2.06,0.06,2.16)$ & 0.05 \\
\hline $\mathrm{C}_{53}$ & $(1.63,2.14,3.64)$ & $(1.41,1.83,3.29)$ & $(3.04,3.98,6.93)$ & 4.65 & $(-1.66,0.31,2.23)$ & 0.29 \\
\hline
\end{tabular}

Table 5. Sum of influences exerted on and received between dimensions

\begin{tabular}{|c|c|c|c|c|c|c|}
\hline $\begin{array}{c}\text { Di- } \\
\text { men- } \\
\text { sion }\end{array}$ & $\tilde{r}$ & $\tilde{d}$ & $\tilde{r}+\tilde{d}$ & BNP & $\tilde{r}-\tilde{d}$ & BNP \\
\hline $\mathrm{D}_{1}$ & $(0.56,0.74,1.27)$ & $(0.63,0.8,1.32)$ & $(1.19,1.54,2.59)$ & 1.77 & $(-0.76,-0.06,0.64)$ & -0.06 \\
\hline $\mathrm{D}_{2}$ & $(0.55,0.73,1.27)$ & $(0.39,0.56,1.08)$ & $(0.95,1.29,2.35)$ & 1.53 & $(-0.53,0.18,0.87)$ & 0.17 \\
\hline $\mathrm{D}_{3}$ & $(0.57,0.75,1.28)$ & $(0.59,0.78,1.30)$ & $(1.16,1.52,2.58)$ & 1.75 & $(-0.74,-0.03,0.68)$ & -0.03 \\
\hline $\mathrm{D}_{4}$ & $(0.52,0.68,1.18)$ & $(0.67,0.85,1.37)$ & $(1.18,1.53,2.55)$ & 1.76 & $(-0.86,-0.18,0.51)$ & -0.17 \\
\hline $\mathrm{D}_{5}$ & $(0.53,0.70,1.21)$ & $(0.44,0.61,1.12)$ & $(0.97,1.31,2.33)$ & 1.54 & $(-0.60,0.09,0.77)$ & 0.09 \\
\hline
\end{tabular}

From Table 4 , it can be seen that labor $\left(\mathrm{C}_{12}\right)$, free port zone $\left(\mathrm{C}_{33}\right)$, and internationaliztion $\left(\mathrm{C}_{42}\right)$ have large $(\tilde{r}+\tilde{d})$ values whereas preferential program $\left(\mathrm{C}_{22}\right)$, regulations $\left(\mathrm{C}_{23}\right)$, and operational model $\left(\mathrm{C}_{51}\right)$ have relatively small $(\tilde{r}+\tilde{d})$ values. In addition, administrative efficiency $\left(\mathrm{C}_{21}\right)$, preferential program $\left(\mathrm{C}_{22}\right)$, and utility $\left(\mathrm{C}_{13}\right)$ possess high positive $(\tilde{r}-\tilde{d})$ values, but labor $\left(\mathrm{C}_{12}\right)$, industrialization $\left(\mathrm{C}_{41}\right)$, and internationalization $\left(\mathrm{C}_{42}\right)$ have notably negative $(\tilde{r}-\tilde{d})$ values. In terms of dimension (Table 5), government $\left(\mathrm{D}_{2}\right)$ and management $\left(\mathrm{D}_{5}\right)$ show positive $(\tilde{r}-\tilde{d})$ values whereas the other dimensions have negative $(\tilde{r}-\tilde{d})$ values. A factor or dimension with a positive $(\tilde{r}-\tilde{d})$ value will influence other factors or dimensions more than it is influenced. A positive $(\tilde{r}-\tilde{d})$ value indicates a causal factor and a negative $(\tilde{r}-\tilde{d})$ value indicates an affected factor. The $(\tilde{r}+\tilde{d})$ value shows the total degree of influence within the system. A large value indicates an element that will affect other dimensions (or factors) as well as the degree that it is affected by other dimensions (or factors). Thus, the $(\tilde{r}+\tilde{d})$ value plays a pivotal role in the system.

According to the total influence matrix and Table 5, the system can be visualized by drawing an INRM of the four dimensions, as illustrated in Fig. 1. In the INRM, we used the $(\tilde{r}+\tilde{d})$ values from Table 5 as the $\mathrm{X}$ axis and the $(\tilde{r}-\tilde{d})$ values as the $\mathrm{Y}$ axis. As shown in Fig. 1 , the dimensions of government $\left(D_{2}\right)$ and management $\left(D_{5}\right)$ have positive $(\tilde{r}-\tilde{d})$ values, which are the causal dimensions. The infrastructure $\left(D_{3}\right)$, cost $\left(D_{1}\right)$, and business environment $\left(D_{4}\right)$ dimensions have negative $(\tilde{r}-\tilde{d})$ values and are deemed to be affected 
dimensions. Because the government $\left(D_{2}\right)$ and management $\left(D_{5}\right)$ are the causes of the system, they will affect other dimensions more than they are affected. To further explore the network relationship of government $\left(D_{2}\right)$ and management $\left(D_{5}\right)$, the INRMs for those two dimensions are used (Fig. 2 and 3). Fig. 2 indicates that administrative efficiency $\left(\mathrm{C}_{21}\right)$ will affect the preferential program $\left(\mathrm{C}_{22}\right)$ and adequate regulation $\left(\mathrm{C}_{23}\right)$. The preferential program $\left(\mathrm{C}_{22}\right)$ will influence adequate regulation $\left(\mathrm{C}_{23}\right)$. Therefore, administrative efficiency $\left(\mathrm{C}_{21}\right)$ is the causal factor of the government $\left(\mathrm{D}_{2}\right)$ subsystem. Similarly, Fig. 3 shows that professional personnel $\left(\mathrm{C}_{53}\right)$ will affect operation model $\left(\mathrm{C}_{51}\right)$ and enterprise recruitment $\left(\mathrm{C}_{52}\right)$, which is a causal factor in the management $\left(\mathrm{D}_{5}\right)$ subsystem.

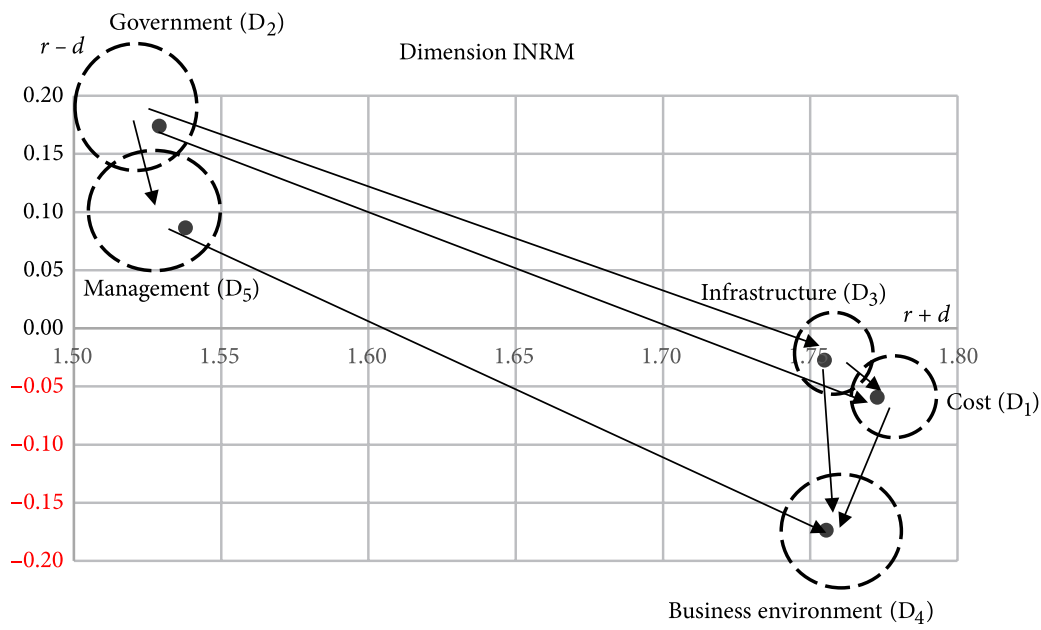

Figure 1. The INRM of dimensions

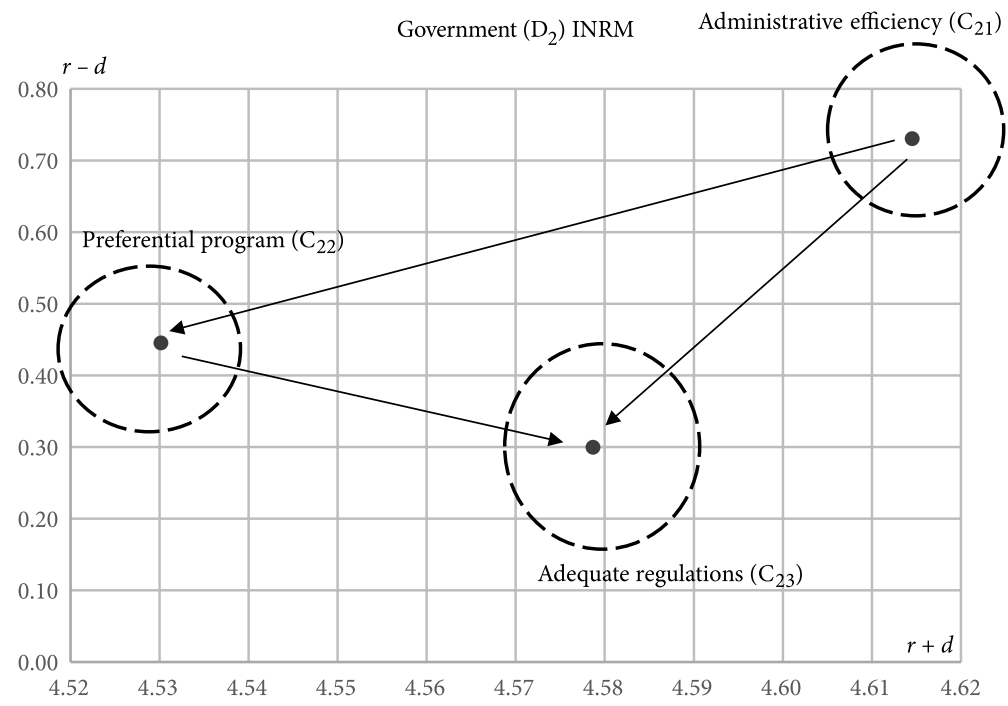

Figure 2 . The INRM of subsystem government $\left(D_{2}\right)$ 


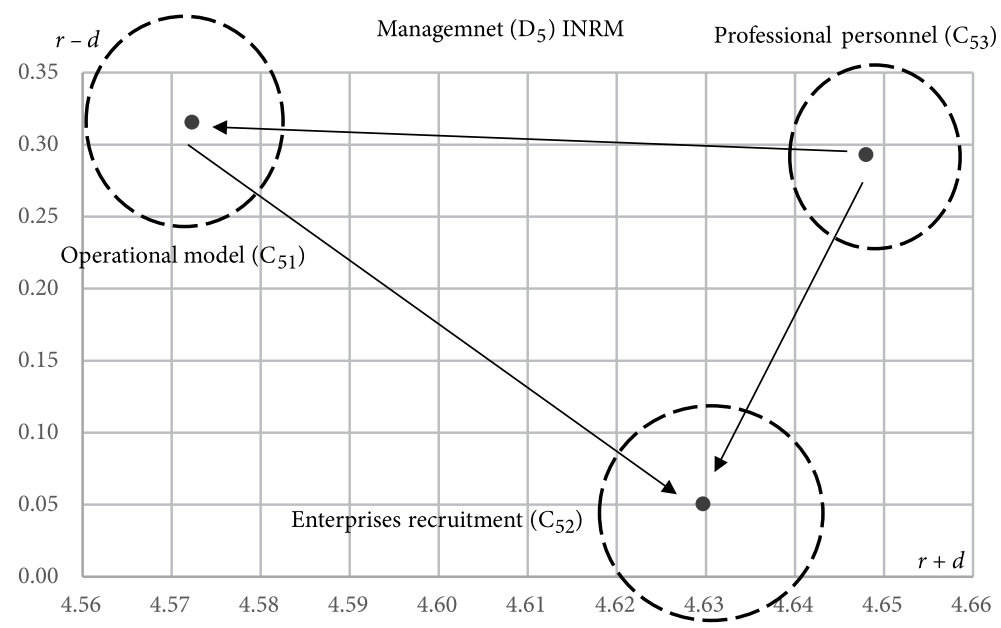

Figure 3. The INRM of subsystem management $\left(D_{5}\right)$

\subsection{Calculate the influence weight}

The applied DANP method, which combines the DEMATEL technique with the concepts of ANP, can be used to calculate the weights of the factors. Using Eqs. (13-17), we can convert the total influence matrix into an unweighted supermatrix. The traditional ANP method assumes the degrees of influence between dimensions are equal, and dictates that the process must divide the unweighted supermatrix by its number of dimensions so that columns sum up to 1 . However, this assumption could be unreasonable because, as can be observed from the results of Table 5, the degrees of influence between dimensions may differ. Therefore, using Eq. (18) to develop the weighted supermatrix, we can raise the supermatrix to its limiting power by Eq. (19) to obtain the weights of various factors (global weights), as shown in Table 6. The DANP approach allows us to derive the local weights of the assessment criteria at their respective hierarchical levels, and the global weights, which help to indicate the absolute weights of individual factors in the overall perspective. The results indicate that business environment $\left(\mathrm{D}_{4}\right)$, with $23 \%$ weight, is the most important dimension. Among the factors, internationalization $\left(\mathrm{C}_{42}\right)$ has the highest priority $(12 \%)$, followed by industrialization $\left(\mathrm{C}_{41}\right)$, in terms of global weight. For the subsystem cost $\left(D_{1}\right)$, the results indicate the labor cost $\left(C_{12}\right)$ has the highest priority (42\%) for enterprise considerations.

Table 6. Influential weights of factors and dimensions

\begin{tabular}{|l|c|c|c|c|c|c|c|}
\hline Dimension & Weight & BNP & Factor & Local weight & BNP & Global weight & BNP \\
\hline \multirow{3}{*}{ Cost $\left(D_{1}\right)$} & $(0.17,0.22,0.37)$ & 0.22 & $C_{11}$ & $(0.25,0.33,0.55)$ & 0.33 & $(0.06,0.07,0.12)$ & 0.07 \\
\cline { 2 - 8 } & & & $C_{12}$ & $(0.35,0.43,0.65)$ & 0.42 & $(0.08,0.10,0.14)$ & 0.09 \\
\cline { 2 - 8 } & & & $C_{13}$ & $(0.18,0.24,0.45)$ & 0.25 & $(0.04,0.05,0.10)$ & 0.06 \\
\hline
\end{tabular}


End of Table 6

\begin{tabular}{|l|c|c|c|c|c|c|c|}
\hline Dimension & Weight & BNP & Factor & Local weight & BNP & Global weight & BNP \\
\hline \multirow{3}{*}{$\begin{array}{l}\text { Government } \\
\left(\mathrm{D}_{2}\right)\end{array}$} & $(0.11,0.16,0.30)$ & 0.16 & $\mathrm{C}_{21}$ & $(0.21,0.31,0.62)$ & 0.31 & $(0.03,0.05,0.10)$ & 0.05 \\
\cline { 2 - 8 } & & & $\mathrm{C}_{22}$ & $(0.23,0.34,0.65)$ & 0.33 & $(0.04,0.05,0.10)$ & 0.05 \\
\hline & $(0.17,0.22,0.36)$ & 0.21 & $\mathrm{C}_{31}$ & $(0.19,0.25,0.42)$ & 0.25 & $(0.04,0.05,0.09)$ & 0.05 \\
\cline { 2 - 8 } & & & $\mathrm{C}_{32}$ & $(0.19,0.25,0.41)$ & 0.25 & $(0.04,0.05,0.09)$ & 0.05 \\
\cline { 2 - 8 } $\begin{array}{l}\text { Infra- } \\
\text { structure } \\
\left(\mathrm{D}_{3}\right)\end{array}$ & & & $\mathrm{C}_{33}$ & $(0.23,0.29,0.45)$ & 0.29 & $(0.05,0.06,0.10)$ & 0.06 \\
\hline \multirow{2}{*}{$\begin{array}{l}\text { Envi- } \\
\text { ronment } \\
\left(\mathrm{D}_{4}\right)\end{array}$} & $(0.18,0.24,0.38)$ & 0.23 & $\mathrm{C}_{41}$ & $(0.37,0.48,0.79)$ & 0.48 & $(0.09,0.11,0.19)$ & 0.11 \\
\hline \multirow{2}{*}{$\begin{array}{l}\text { Mana- } \\
\text { gement }\left(\mathrm{D}_{5}\right)\end{array}$} & $(0.12,0.17,0.31)$ & 0.18 & $\mathrm{C}_{51}$ & $(0.22,0.32,0.61)$ & 0.32 & $(0.04,0.05,0.10)$ & 0.06 \\
\cline { 2 - 8 } & & & $\mathrm{C}_{52}$ & $(0.25,0.35,0.65)$ & 0.35 & $(0.04,0.06,0.11)$ & 0.06 \\
\hline
\end{tabular}

\subsection{Analyze the weighted gap to the aspiration levels}

The weights derived from DANP are incorporated into a modified VIKOR analysis to evaluate the weighted gap in each factor. First, experts survey the performance values of Taoyuan Aerotropolis for each factor. However, performance levels are expressed as fuzzy numbers because of the vague and incomplete information that each expert has. Next, the weighted gaps of Taoyuan Aerotropolis can be calculated by following the steps of the modified VIKOR method, as described in Eqs. (21-23), for each factor and dimension (Table 7). The results indicate how much the weighted gap in each dimension or factor must improve to reach the aspiration level. Table 7 also shows the BNP values obtained from Section 2.4 for comparison. The results indicate that internationalization $\left(\mathrm{C}_{42}\right)$ and adequate regulation $\left(\mathrm{C}_{23}\right)$ have the largest weighted gap values $(0.30)$, followed by preferential program $\left(\mathrm{C}_{22}\right)$ and industrialization $\left(\mathrm{C}_{41}\right)$ (0.28). Currently, these factors are behind schedule and must be accelerated for the coordinated development of Taoyuan Aerotropolis. The results also show that the airport $\left(C_{31}\right)$ and air routes $\left(C_{32}\right)$ have better performance levels with smallest weighted gap $(0.12)$. Regarding dimensions, government $\left(\mathrm{D}_{2}\right)$ has the largest weighted gap (0.53) whereas infrastructure $\left(D_{3}\right)$ has the smallest weighted gap (0.37). Notably, even the smallest weighted gap requires an increase of more than one-third to achieve the aspiration level, indicating that much room for improvement exists in Taoyuan Aerotropolis. This weighted gap analysis and the INRM provide useful information that can aid decision makers. The derived management implications are discussed in Section 4. 
Table 7. Weighted-gap analysis for dimensions and factors

\begin{tabular}{|l|c|c|c|c|c|c|}
\hline Dimension & $\mathrm{R}_{\mathrm{i}}$ & $\mathrm{BNP}$ & Factor & Performance & Weighted-gap & BNP \\
\hline \multirow{4}{*}{ Cost $\left(\mathrm{D}_{1}\right)$} & $(0.22,0.34,0.67)$ & 0.41 & $\mathrm{C}_{11}$ & $(4.62,5.62,6.54)$ & $(0.09,0.15,0.30)$ & 0.18 \\
\cline { 2 - 7 } & & & $\mathrm{C}_{12}$ & $(4.00,5.99,5.92)$ & $(0.14,0.21,0.39)$ & 0.25 \\
\cline { 2 - 7 } & & & $\mathrm{C}_{13}$ & $(4.23,5.23,6.23)$ & $(0.07,0.12,0.26)$ & 0.15 \\
\hline \multirow{3}{*}{$\begin{array}{l}\text { Government } \\
\left(\mathrm{D}_{2}\right)\end{array}$} & $(0.25,0.42,0.93)$ & 0.53 & $\mathrm{C}_{21}$ & $(4.24,5.23,6.23)$ & $(0.08,0.15,0.36)$ & 0.20 \\
\cline { 2 - 7 } & & & $\mathrm{C}_{22}$ & $(2.49,3.39,4.38)$ & $(0.13,0.22,0.49)$ & 0.28 \\
\hline \multirow{3}{*}{$\begin{array}{l}\text { Infra- } \\
\text { structure } \\
\left(\mathrm{D}_{3}\right)\end{array}$} & $(0.19,0.31,0.61)$ & 0.37 & $\mathrm{C}_{31}$ & $(5.00,6.00,7.00)$ & $(0.06,0.10,0.21)$ & 0.12 \\
\cline { 2 - 7 } & & & $\mathrm{C}_{32}$ & $(4.92,5.92,6.92)$ & $(0.06,0.10,0.21)$ & 0.12 \\
\cline { 2 - 7 } & & & $\mathrm{C}_{33}$ & $(3.64,4.48,5.46)$ & $(0.10,0.16,0.29)$ & 0.18 \\
\hline $\begin{array}{l}\text { Environment } \\
\left(\mathrm{D}_{4}\right)\end{array}$ & $(0.23,0.37,0.72)$ & 0.44 & $\mathrm{C}_{41}$ & $(4.15,5.15,6.15)$ & $(0.14,0.24,0.47)$ & 0.28 \\
\cline { 2 - 7 } & & & $\mathrm{C}_{42}$ & $(4.15,5.15,6.15)$ & $(0.16,0.25,0.48)$ & 0.30 \\
\hline \multirow{3}{*}{$\begin{array}{l}\text { Management } \\
\left(\mathrm{D}_{5}\right)\end{array}$} & $(0.22,0.37,0.81)$ & 0.46 & $\mathrm{C}_{51}$ & $(3.23,4.23,5.23)$ & $(0.11,0.19,0.41)$ & 0.24 \\
\cline { 2 - 7 } & & & $\mathrm{C}_{52}$ & $(3.62,4.62,5.62)$ & $(0.11,0.19,0.42)$ & 0.24 \\
\cline { 2 - 7 } & & & $\mathrm{C}_{53}$ & $(3.77,4.77,5.77)$ & $(0.11,0.17,0.37)$ & 0.22 \\
\hline
\end{tabular}

\section{Discussion}

The proposed hybrid model provides a systemic analytical model for developing a successful aerotropolis. The model not only considers the interdependencies among dimensions and factors but also includes the different degrees of influence among the dimensions. Linguistic variables and TFNs were applied in the model to cope with decision-maker uncertainties and yield a reasonable representation of the real world. Another advantage of this model, and one which constitutes the contribution of this study to the field, is that the INRM can reveal the optimal direction of improvement rather than merely ranking the weighted gaps in a modified VIKOR. For example, the direction of influence within the dimensions (Fig. 1) shows that government $\left(D_{1}\right)$ and management $\left(D_{5}\right)$ affect infrastructure $\left(D_{3}\right)$, business environment $\left(D_{4}\right)$, and cost $\left(D_{1}\right)$. These results imply that government and management are key to developing a successful aerotropolis, and that the other dimensions are affected dimensions. Therefore, managers should focus on strengthening the role of government and raising the management abilities of Taoyuan Aerotropolis Company. The weighted gap analysis shows that government and management have the largest weighted gap values, as shown in Table 7 .

More specifically, Fig. 2 shows the influence direction within the government subsystem. It indicates that administrative efficiency $\left(\mathrm{C}_{21}\right)$ affects preferential program $\left(\mathrm{C}_{22}\right)$ and adequate regulation $\left(\mathrm{C}_{23}\right)$. The preferential program is a crucial factor for attracting enterprises to the aerotropolis. Adequate regulation provides legal assurance for enterprises. However, both the preferential program and adequate regulation rely on administrative efficiency. Currently, insufficient regulation seems to be an urgent problem obstructing the development of Taoyuan Aerotropolis. The gap analysis confirms this by showing that adequate regulation has the largest weighted gap (Table 7). Therefore, accelerating the legislation processes and 
providing a persuasive preferential program for enterprises should be the highest priorities. The subsystem of management (Fig. 3) offers another direction for improvement. Fig. 3 shows that professional personnel $\left(\mathrm{C}_{53}\right)$ constitute the key causative factor affecting the operational model $\left(\mathrm{C}_{51}\right)$ and enterprise recruitment $\left(\mathrm{C}_{52}\right)$. Although the Taiwan government established Taoyuan Aerotropolis Company to integrate and manage the different resources and departments, the optimal business model for the company is debatable. Thus, to recruit professional personnel from international markets should be the most essential issue for Taoyuan Aerotropolis Company. Professional personnel can enable the company to launch the business model that is most suitable for the situation in Taiwan and attract world-leading international companies to move into Taoyuan Aerotropolis.

The influential weights reflect the importance of factors for developing a successful aerotropolis. Table 6 indicates that internationalization $\left(\mathrm{C}_{42}\right)$ is the most important factor for developing a successful aerotropolis, followed by industrialization $\left(\mathrm{C}_{41}\right)$ and labor $\operatorname{cost}\left(\mathrm{C}_{12}\right)$. This implies that the levels of internationalization and industrialization are crucial considerations when enterprises consider whether to invest in an aerotropolis. Labor cost is another essential component for any corporate investment decision. However, gap analysis (Table 7) shows that there are large gaps for internationalization and labor cost at the current stage of development of Taoyuan Aerotropolis. This means that Taiwan should further open its markets to attract international companies. Labor costs could be reduced by importing foreign labor. However, a more open market requires a reduction in government interference in foreign exchange and to allow international and domestic enterprises to more easily acquire land and capital. On the other hand, importing foreign labor could trigger protests from Taiwanese workers and increase the unemployment rate in Taiwan. Such side effects should be considered when any related decision is made. Figure 2 shows that either adequate regulations are required or a preferential program with an efficient administration. After the labor cost, analysis also shows the land issue to be of concern to the experts. Currently, the existing aerotropolis does not have sufficient space for more companies to move in. The government needs to incorporate some private land into the area. However, there is a balanced between fair compensation to private landowners to avoid resistance to the acquisition of their land while minimizing the financial burden on the Taoyuan Aerotropolis.

In the gap analysis, ground transportation $\left(\mathrm{C}_{33}\right)$ has the largest gap in the infrastructure $\left(\mathrm{D}_{3}\right)$ dimension. Transport infrastructure, as a facilitator of access, is recognized as fundamental to the development of the aerotropolis and the emerging airport metropolis. Access to and from the aerotropolis is important for various users, including airport, commercial, and retail workers inside the aerotropolis site, as well as logistics organizations picking up and delivering freight. At its current stage, Taoyuan Aerotropolis has satisfactory highway systems; however, it is yet to be linked to the Taipei mass rapid transport (MRT) system. Completing the MRT line as soon as possible could be a major challenge for Taoyuan Aerotropolis. Enterprise recruitment $\left(\mathrm{C}_{52}\right)$ is another factor with a large performance gap for Taoyuan Aerotropolis. Without enterprises resident within the aerotropolis, Taoyuan Aerotropolis will only function as a large airport and not as a true aerotropolis. According to the INRM of subsystem management (Fig. 3), hiring more professional personnel in Taoyuan Aerotropolis Company could be one means of closing the gap. Because the aerotropolis concept has only 
existed for approximately a decade, Taiwan has few managers or experts who are acquainted with the concept. Taiwan may be able to recruit professional airport managers from other countries. Again, the above discussions demonstrate the usefulness of the proposed model, which not only identifies gaps in performance but also provides a direction for improvement.

Compared with traditional ANP methods, the DANP method provides more information, such as improved directions and visualization graphs representative of the cause and effect factors within the system. In the DANP method the weights are derived directly from the DEMATEL results thereby reducing the time-consuming pairwise comparisons involved in the original ANP calculation. The modified VIKOR gap analysis has several advantages over other similar methods. It considers different definitions of distance and replaces the relatively good concepts with the aspiration level. For example, our results show that airport $\left(\mathrm{C}_{31}\right)$ has a weighted gap of 0.12 , but with the original VIKOR method, this factor has an almost zero gap. Our results indicate that there are currently areas for improvement at the airport to achieve the aspiration levels, while the original VIKOR implies that the current situation is satisfactory. The proposed method seems more reasonable than the original method in today's competitive markets.

\section{Conclusions and remarks}

As an airport develops into an aerotropolis, it expands its operational management functions to include nonaeronautical functions. Major airports around the world have actually established commercial real estate divisions to develop landside areas and foster commercial development beyond airport boundaries. Numerous countries seek to promote economic development by answering two questions: What are the key factors for successful aerotropolis development and what are the gaps that a developing aerotropolis must fill? Our model improves upon prior methods that neglect the interdependence of the factors and the uncertainties of expert opinions. Our discussion centers on aspiration levels and weighted gaps to show a path to improvement rather than an oversimplified ranking of factors. Weighted gaps are also a convenient means to observe items that perform poorly so that improvement strategies can be prioritized. Our results indicate that internationalization, industrialization, and labor cost are the key factors for developing a successful aerotropolis. However, according to the INRM, shortfalls in administrative efficiency and professional personnel cause major problems. We also made suggestions regarding the development of Taoyuan Aerotropolis according to the gap analysis and INRM.

Although the present study makes some contributions to the field of research, limitations remain. Our study applies a general model to the specific case of Taoyuan Aerotropolis, and thus our conclusions are only one specific portion of our model. Data from other countries could be used to test our model. Furthermore, historic airport designs date back to a time before air travel had its current economic significance; thus, historic airport designs are more static than are those of aerotropolese, which are dynamic phenomena guided by forwardlooking concepts. The future development of aerotropolises will be driven by further global integration and a requirement for speed; the current model is only a starting point in considering these factors. A future longitudinal study could allow the investigation of our model 
across different time periods and comparisons between the demands of different times could provide more insight into aerotropolis development.

\section{References}

Appold, S. J. 2013. A short primer on Aerotropolis and Airport city planning: Draft. University of North Carolina at Chapel Hill.

Baker, D. C.; Freestone, R. 2010. The Airport city: a new business model for airport development, in Critical Issues in Air Transport Economics and Business. Routledge, 150-164.

Barros, A. G. D.; Somasundaraswaran, A. K.; Wirasinghe, S. C. 2007. Evaluation of level of service for transfer passengers at airports, Journal of Air Transport Management 13(5): 293-298. https://doi.org/10.1016/j.jairtraman.2007.04.004

Canaday, H. 2000. Planning the "Aerotropolis": Henry Canaday talks to John Kasarda, Airport World 5(5): 52-53.

Charles, M. B.; Barnes, P.; Ryan, N.; Clayton, J. 2007. Airport futures: towards a critique of the aerotropolis model, Futures 39(9): 1009-1028. https://doi.org/10.1016/j.futures.2007.03.017

Chen, Y. C.; Lien, H. P.; Liu, C. H.; Liou, J. J. H; Tzeng, G. H.; Yang, L. S. 2011. Fuzzy MCDM approach for selecting the best environment-watershed plan, Applied Soft Computing 11(1): 265-275. https://doi.org/10.1016/j.asoc.2009.11.017

Chou, C. C.; Liu, L. J.; Huang, S. F.; Yih, J. M.; Han, T. C. 2011. An evaluation of airline service quality using the Fuzzy weighted SERVQUAL method, Applied Soft Computing 11(2): 2117-2128. https://doi.org/10.1016/j.asoc.2010.07.010

Freestone, R.; Baker, D.; Stevens, N. 2011. Managing airport land development under regulatory uncertainty, Research in Transportation Business \& Management 1: 101-108. https://doi.org/10.1016/j.rtbm.2011.05.006

Gardiner, J.; Ison, S.; Humphreys, I. 2005. Factors influencing cargo airline's choice of airport: an international survey, Journal of Air Transport Management 11(6): 393-399. https://doi.org/10.1016/j.jairtraman.2005.05.004

Janic, M.; Reggiani, A. 2002. An application of the multiple criteria decision making (MCDM) analysis to the selection of a new hub airport, European Journal of Transport and Infrastructure Research 2(2):113-141.

Jayalath, J. T. D.; Bandara, J. M. S. J. 2001. Future of Colombo airport (CMB) as an airline hub, Journal of Air Transportation World Wide 6(2): 117-128.

Kasarda, J. D. 2005. Gateway airports, speed and the rise of the aerotropolis, in D. V. Gibson, M. V. Heitor, A. Ibarra-Yunez (Eds.). Learning and knowledge for the network society. Perdue University Press, West Lafayette, IN, 99-108.

Kasarda, J. D. 2006. The rise of the aerotropolis, The Next American City 10: 35-37.

Kasarda, J. D. 2014. Planning a competitive Aerotropolis, in J. H. Peoples Jr. (Ed.). The economics of international air transportation. West Yorkshire: Emerald Group Publishing. https://doi.org/10.1108/S2212-160920140000004010

Keast, R. L.; Baker, D. C.; Brown, K. 2008. Balancing infrastructure for the airport metropolis, in International conference on infrastructure systems: building networks for a brighter future, 10-12 November, Rotterdam, Netherlands.

Keumi, C.; Murakami, H. 2012. The role of schedule delays on passengers' choice of access modes: a case study of Japan's international hub airports, Transportation Research Part E 48(5): 1023-1031. https://doi.org/10.1016/j.tre.2012.03.005 
Kim, J. Y.; Park, Y. H. 2012. Connectivity analysis of transshipments at a cargo hub airport, Journal of Air Transport Management 18(1): 12-15. https://doi.org/10.1016/j.jairtraman.2011.05.001

Kratzsch, U.; Sieg, G. 2011. Non-aviation revenues and their implications for airport regulation, Transportation Research Part E 47(5): 755-763. https://doi.org/10.1016/j.tre.2011.02.010

Liou, J. J. H.; Chuang, Y. C.; Tzeng, G. H. 2014. A fuzzy integral-based model for supplier evaluation and improvement, Information Sciences 266: 199-217. https://doi.org/10.1016/j.ins.2013.09.025

Liou, J. H. J.; Tamosaitiene, J.; Zavadskas, E. K.; Tzeng, G. H. 2016. New hybrid COPRAS-G MADM Model for improving and selecting suppliers in green supply chain management, International Journal of Production Research 54(1): 114-134. https://doi.org/10.1080/00207543.2015.1010747

Liu, H. C.; You, J. X.; Ding, X. F.; Su, Q. 2015a. Improving risk evaluation in FMEA with a hybrid multiple criteria decision making method. International Journal of Quality and Reliability Management 32(7): 763-782. https://doi.org/10.1108/IJQRM-10-2013-0169

Liu, H. C.; You, J. X.; Lin, Q. L.; Li, H. 2015b. Risk assessment in system FMEA combining fuzzy weighted average with fuzzy decision-making trial and evaluation laboratory, International Journal of Computer Integrated Manufacturing 28(7): 701-714. https://doi.org/10.1080/0951192X.2014.900865

Menou, A.; Benallou, A.; Lahdelma, R.; Salminen, P. 2010. Decision support for centralizing cargo at a moroccan airport hub using stochastic multi-criteria acceptability analysis, European Journal of Operational Research 204(3): 621-629. https://doi.org/10.1016/j.ejor.2009.11.021

Opricovic, S.; Tzeng, G. H. 2004. Compromise solution by MCDM methods: a comparative analysis of VIKOR and TOPSIS, European Journal of Operational Research 156(2): 445-455. https://doi.org/10.1016/S0377-2217(03)00020-1

Pagliari, R. 2005. Developments in the supply of direct international air services from airports in Scotland, Journal of Air Transport Management 11(4): 249-257.

https://doi.org/10.1016/j.jairtraman.2005.01.002

Peng, K. H.; Tzeng, G. H. 2013. A hybrid dynamic MADM model for problems-improvement in economics and business, Technological and Economic Development of Economy 19(4): 638-660. https://doi.org/10.3846/20294913.2013.837114

Rendeiro, R.; Cejas, M. 2006. Tourism service quality begins at the airport, Tourism Management 27(5): 874-877. https://doi.org/10.1016/j.tourman.2005.05.005

Shen, K. Y.; Yan, M. R.; Tzeng, G. H. 2014. Combining VIKOR-DANP model for glamour stock selection and stock performance improvement, Knowledge-Based Systems 58(1): 86-97. https://doi.org/10.1016/j.knosys.2013.07.023

Skouloudis, A.; Evangelinos, K.; Moraitis, S. 2012. Accountability and stakeholder engagement in the airport industry: an assessment of airports' CSR reports, Journal of Air Transport Management 18(1): 16-20. https://doi.org/10.1016/j.jairtraman.2011.06.001

Stevens, N.; Baker, D.; Freestone, R. 2010. Airports in their urban settings: towards a conceptual model of interfaces in the Australian context, Journal of Transport Geography 18(2): 276-284. https://doi.org/10.1016/j.jtrangeo.2009.05.007

Tsui, C. W.; Tzeng, G. H.; Wen, U. P. 2015. A hybrid MCDM approach for improving the performance of green suppliers in the TFT-LCD industry, International Journal of Production Research 53(21): 6436-6454. https://doi.org/10.1080/00207543.2014.935829

Tzeng, G. H.; Teng, M. H.; Chen, J. J.; Opricovic, S. 2002. Multicriteria selection for a restaurant location in Taipei, International Journal of Hospitality Management 21(2): 171-187. https://doi.org/10.1016/S0278-4319(02)00005-1

UK Department for Transport. 2003. The future of air transport-White Paper and Civil Aviation Bill [online], [cited on July 2015]. Available from Internet: /http://www.dft.gov.uk/stellent/groups/dft_ aviation/documents/divisionhomepage/029650.hcspS. 
Walker, A. R.; Baker, D. C. 2010. A panning support system for airport city development, in 14th Air Transport Research Society (ATRS) Conference, Porto, Portugal, 6-9 July, 1-11.

Walker, A. R.; Stevens, N. J. 2008. Airport city developments in Australia: land use classification and analysis, in 10th TRAIL Congress and Knowledge Market, Rotterdam, Netherlands, 14-15 October.

Wang, K. J.; Hong, W. C. 2011. Competitive advantage analysis and strategy formulation of airport city development-the case of Taiwan, Transport Policy 18(1): 276-288.

https://doi.org/10.1016/j.tranpol.2010.08.011

Wang, Y. L.; Tzeng, G. H. 2012. Brand marketing for creating brand value based on a MCDM model combining DEMATEL with ANP and VIKOR methods, Expert Systems with Applications 39(5): 5600-5615. https://doi.org/10.1016/j.eswa.2011.11.057

Xu, Z. S.; Yager, R. R. 2008. Dynamic intuitionistic fuzzy mutli-attribute decision making, International Journal of Approximate Reasoning 48(1): 246-262. https://doi.org/10.1016/j.ijar.2007.08.008

Yeo, G. T.; Wang, Y.; Chou, C. C. 2013. Evaluating the competitiveness of the aerotropolises in East Asia, Journal of Air Transport Management 32: 24-31. https://doi.org/10.1016/j.jairtraman.2013.06.004

You, X. Y.; You, J. X.; Liu, H. C.; Zhen, L. 2015. Group multi-criteria supplier selection using an extended VIKOR method with interval 2-tuple linguistic information, Expert Systems with Applications 42(4): 1906-1916. https://doi.org/10.1016/j.eswa.2014.10.004

\section{APPENDIX}

The initial direct influence matrix

Table A1. The lower values of direct influence matrix

\begin{tabular}{|l|c|c|c|c|c|c|c|c|c|c|c|c|c|c|c|}
\hline & $C_{11}$ & $C_{12}$ & $C_{13}$ & $C_{21}$ & $C_{22}$ & $C_{23}$ & $C_{31}$ & $C_{32}$ & $C_{33}$ & $C_{34}$ & $C_{41}$ & $C_{42}$ & $C_{51}$ & $C_{52}$ & $C_{53}$ \\
\hline$C_{11}$ & 0.00 & 0.60 & 0.40 & 0.50 & 0.17 & 0.23 & 0.46 & 0.38 & 0.50 & 0.21 & 0.23 & 0.42 & 0.31 & 0.33 & 0.27 \\
\hline$C_{12}$ & 0.38 & 0.00 & 0.44 & 0.21 & 0.42 & 0.38 & 0.37 & 0.31 & 0.48 & 0.29 & 0.44 & 0.60 & 0.21 & 0.21 & 0.31 \\
\hline$C_{13}$ & 0.46 & 0.50 & 0.00 & 0.50 & 0.19 & 0.17 & 0.42 & 0.31 & 0.38 & 0.23 & 0.27 & 0.35 & 0.15 & 0.21 & 0.42 \\
\hline$C_{21}$ & 0.48 & 0.62 & 0.42 & 0.00 & 0.13 & 0.35 & 0.50 & 0.33 & 0.46 & 0.29 & 0.37 & 0.35 & 0.21 & 0.40 & 0.29 \\
\hline$C_{22}$ & 0.13 & 0.62 & 0.15 & 0.13 & 0.00 & 0.38 & 0.25 & 0.27 & 0.38 & 0.23 & 0.38 & 0.38 & 0.54 & 0.44 & 0.46 \\
\hline$C_{23}$ & 0.40 & 0.52 & 0.21 & 0.21 & 0.38 & 0.00 & 0.27 & 0.27 & 0.40 & 0.15 & 0.44 & 0.50 & 0.27 & 0.27 & 0.19 \\
\hline$C_{31}$ & 0.40 & 0.52 & 0.12 & 0.27 & 0.12 & 0.13 & 0.00 & 0.52 & 0.54 & 0.38 & 0.48 & 0.56 & 0.25 & 0.35 & 0.33 \\
\hline$C_{32}$ & 0.44 & 0.48 & 0.13 & 0.12 & 0.38 & 0.23 & 0.42 & 0.00 & 0.44 & 0.31 & 0.46 & 0.63 & 0.17 & 0.35 & 0.27 \\
\hline$C_{33}$ & 0.40 & 0.60 & 0.23 & 0.27 & 0.29 & 0.33 & 0.44 & 0.46 & 0.00 & 0.37 & 0.44 & 0.54 & 0.46 & 0.40 & 0.35 \\
\hline$C_{34}$ & 0.27 & 0.37 & 0.10 & 0.15 & 0.19 & 0.19 & 0.38 & 0.31 & 0.40 & 0.00 & 0.29 & 0.31 & 0.33 & 0.38 & 0.27 \\
\hline$C_{41}$ & 0.40 & 0.52 & 0.25 & 0.06 & 0.15 & 0.17 & 0.29 & 0.40 & 0.50 & 0.33 & 0.00 & 0.48 & 0.19 & 0.21 & 0.31 \\
\hline$C_{42}$ & 0.29 & 0.58 & 0.37 & 0.17 & 0.19 & 0.42 & 0.46 & 0.56 & 0.46 & 0.27 & 0.48 & 0.00 & 0.17 & 0.17 & 0.27 \\
\hline$C_{51}$ & 0.38 & 0.62 & 0.12 & 0.08 & 0.29 & 0.29 & 0.40 & 0.27 & 0.46 & 0.38 & 0.42 & 0.42 & 0.00 & 0.27 & 0.27 \\
\hline$C_{52}$ & 0.44 & 0.58 & 0.15 & 0.21 & 0.13 & 0.19 & 0.33 & 0.37 & 0.42 & 0.31 & 0.42 & 0.37 & 0.27 & 0.00 & 0.15 \\
\hline$C_{53}$ & 0.42 & 0.63 & 0.35 & 0.37 & 0.23 & 0.29 & 0.35 & 0.38 & 0.37 & 0.31 & 0.44 & 0.44 & 0.12 & 0.08 & 0.00 \\
\hline
\end{tabular}


Table A2. The middle values of direct influence matrix

\begin{tabular}{|l|l|l|l|l|l|l|l|l|l|l|l|l|l|l|l|}
\hline & $C_{11}$ & $C_{12}$ & $C_{13}$ & $C_{21}$ & $C_{22}$ & $C_{23}$ & $C_{31}$ & $C_{32}$ & $C_{33}$ & $C_{34}$ & $C_{41}$ & $C_{42}$ & $C_{51}$ & $C_{52}$ & $C_{53}$ \\
\hline$C_{11}$ & 0.00 & 0.85 & 0.63 & 0.73 & 0.40 & 0.44 & 0.69 & 0.60 & 0.75 & 0.42 & 0.44 & 0.63 & 0.50 & 0.54 & 0.48 \\
\hline$C_{12}$ & 0.60 & 0.00 & 0.67 & 0.33 & 0.65 & 0.60 & 0.56 & 0.46 & 0.73 & 0.48 & 0.67 & 0.85 & 0.38 & 0.38 & 0.50 \\
\hline$C_{13}$ & 0.69 & 0.75 & 0.00 & 0.75 & 0.37 & 0.37 & 0.65 & 0.48 & 0.60 & 0.44 & 0.48 & 0.58 & 0.29 & 0.40 & 0.63 \\
\hline$C_{21}$ & 0.73 & 0.87 & 0.65 & 0.00 & 0.27 & 0.52 & 0.75 & 0.56 & 0.71 & 0.52 & 0.60 & 0.58 & 0.37 & 0.62 & 0.52 \\
\hline$C_{22}$ & 0.35 & 0.87 & 0.27 & 0.25 & 0.00 & 0.60 & 0.44 & 0.46 & 0.60 & 0.44 & 0.62 & 0.62 & 0.79 & 0.65 & 0.69 \\
\hline$C_{23}$ & 0.62 & 0.77 & 0.37 & 0.40 & 0.60 & 0.00 & 0.46 & 0.46 & 0.63 & 0.38 & 0.67 & 0.75 & 0.46 & 0.48 & 0.38 \\
\hline$C_{31}$ & 0.63 & 0.77 & 0.31 & 0.46 & 0.25 & 0.27 & 0.00 & 0.75 & 0.79 & 0.63 & 0.73 & 0.81 & 0.48 & 0.58 & 0.56 \\
\hline$C_{32}$ & 0.65 & 0.73 & 0.31 & 0.25 & 0.58 & 0.40 & 0.63 & 0.00 & 0.65 & 0.52 & 0.69 & 0.88 & 0.37 & 0.58 & 0.48 \\
\hline$C_{33}$ & 0.63 & 0.85 & 0.38 & 0.44 & 0.46 & 0.50 & 0.67 & 0.67 & 0.00 & 0.58 & 0.69 & 0.79 & 0.67 & 0.63 & 0.58 \\
\hline$C_{34}$ & 0.48 & 0.62 & 0.23 & 0.35 & 0.40 & 0.38 & 0.63 & 0.54 & 0.65 & 0.00 & 0.54 & 0.52 & 0.54 & 0.60 & 0.48 \\
\hline$C_{41}$ & 0.63 & 0.77 & 0.44 & 0.19 & 0.31 & 0.33 & 0.52 & 0.63 & 0.75 & 0.56 & 0.00 & 0.71 & 0.40 & 0.40 & 0.00 \\
\hline$C_{42}$ & 0.52 & 0.83 & 0.58 & 0.37 & 0.37 & 0.63 & 0.71 & 0.81 & 0.69 & 0.46 & 0.71 & 0.00 & 0.35 & 0.37 & 0.46 \\
\hline$C_{51}$ & 0.60 & 0.87 & 0.21 & 0.15 & 0.50 & 0.46 & 0.62 & 0.46 & 0.71 & 0.62 & 0.67 & 0.65 & 0.00 & 0.46 & 0.46 \\
\hline$C_{52}$ & 0.65 & 0.83 & 0.31 & 0.33 & 0.33 & 0.31 & 0.52 & 0.60 & 0.67 & 0.52 & 0.67 & 0.60 & 0.46 & 0.00 & 0.33 \\
\hline$C_{53}$ & 0.65 & 0.88 & 0.54 & 0.56 & 0.44 & 0.44 & 0.52 & 0.58 & 0.60 & 0.52 & 0.69 & 0.69 & 0.25 & 0.25 & 0.00 \\
\hline
\end{tabular}

Table A3. The upper values of direct influence matrix

\begin{tabular}{|l|l|l|l|l|l|l|l|l|l|l|l|l|l|l|l|}
\hline & $C_{11}$ & $C_{12}$ & $C_{13}$ & $C_{21}$ & $C_{22}$ & $C_{23}$ & $C_{31}$ & $C_{32}$ & $C_{33}$ & $C_{34}$ & $C_{41}$ & $C_{42}$ & $C_{51}$ & $C_{52}$ & $C_{53}$ \\
\hline$C_{11}$ & 0.00 & 0.98 & 0.85 & 0.88 & 0.65 & 0.69 & 0.87 & 0.79 & 0.90 & 0.65 & 0.65 & 0.79 & 0.67 & 0.75 & 0.69 \\
\hline$C_{12}$ & 0.77 & 0.00 & 0.83 & 0.54 & 0.83 & 0.79 & 0.75 & 0.65 & 0.88 & 0.69 & 0.85 & 0.94 & 0.60 & 0.62 & 0.67 \\
\hline$C_{13}$ & 0.88 & 0.90 & 0.00 & 0.90 & 0.62 & 0.62 & 0.85 & 0.67 & 0.79 & 0.67 & 0.67 & 0.75 & 0.54 & 0.63 & 0.77 \\
\hline$C_{21}$ & 0.90 & 0.94 & 0.81 & 0.00 & 0.52 & 0.71 & 0.94 & 0.79 & 0.90 & 0.71 & 0.81 & 0.79 & 0.58 & 0.79 & 0.73 \\
\hline$C_{22}$ & 0.60 & 0.96 & 0.50 & 0.50 & 0.00 & 0.77 & 0.65 & 0.67 & 0.79 & 0.67 & 0.79 & 0.79 & 0.94 & 0.81 & 0.87 \\
\hline$C_{23}$ & 0.79 & 0.90 & 0.60 & 0.62 & 0.79 & 0.00 & 0.67 & 0.67 & 0.81 & 0.63 & 0.87 & 0.90 & 0.67 & 0.67 & 0.62 \\
\hline$C_{31}$ & 0.81 & 0.92 & 0.56 & 0.71 & 0.50 & 0.52 & 0.00 & 0.87 & 0.92 & 0.83 & 0.88 & 0.92 & 0.71 & 0.79 & 0.75 \\
\hline$C_{32}$ & 0.85 & 0.92 & 0.54 & 0.50 & 0.75 & 0.62 & 0.79 & 0.00 & 0.79 & 0.71 & 0.87 & 0.98 & 0.58 & 0.77 & 0.65 \\
\hline$C_{33}$ & 0.83 & 0.96 & 0.63 & 0.67 & 0.67 & 0.67 & 0.83 & 0.85 & 0.00 & 0.77 & 0.85 & 0.92 & 0.85 & 0.83 & 0.77 \\
\hline$C_{34}$ & 0.69 & 0.83 & 0.46 & 0.60 & 0.65 & 0.62 & 0.83 & 0.75 & 0.83 & 0.00 & 0.75 & 0.73 & 0.71 & 0.75 & 0.67 \\
\hline$C_{42}$ & 0.79 & 0.90 & 0.65 & 0.44 & 0.54 & 0.56 & 0.73 & 0.83 & 0.87 & 0.75 & 0.00 & 0.87 & 0.65 & 0.63 & 0.00 \\
\hline$C_{44}$ & 0.73 & 0.96 & 0.73 & 0.62 & 0.58 & 0.79 & 0.83 & 0.92 & 0.85 & 0.67 & 0.85 & 0.00 & 0.58 & 0.62 & 0.67 \\
\hline$C_{51}$ & 0.79 & 0.96 & 0.44 & 0.40 & 0.71 & 0.65 & 0.79 & 0.69 & 0.88 & 0.83 & 0.83 & 0.83 & 0.00 & 0.65 & 0.65 \\
\hline$C_{52}$ & 0.81 & 0.96 & 0.52 & 0.54 & 0.56 & 0.52 & 0.69 & 0.77 & 0.81 & 0.73 & 0.83 & 0.77 & 0.67 & 0.00 & 0.58 \\
\hline$C_{53}$ & 0.83 & 0.96 & 0.71 & 0.73 & 0.63 & 0.63 & 0.69 & 0.73 & 0.75 & 0.71 & 0.83 & 0.85 & 0.50 & 0.50 & 0.00 \\
\hline
\end{tabular}

